\title{
CROSS-BORDER BANKING AND MACROPRUDENTIAL POLICIES IN ASYMMETRIC MONETARY UNIONS
}

\author{
LENA DRÄGER \\ Leibniz Universität Hannover
}

Christian R. Proaño

Otto-Friedrich-Universität Bamberg and Universidad San Francisco de Quito

\begin{abstract}
Against the background of the emergence of macroeconomic imbalances within the European Monetary Union (EMU), we investigate in this paper the macroeconomic consequences of cross-border banking in monetary unions such as the Euro area. For this purpose, we incorporate a union-wide banking sector along the lines in an otherwise standard two-region monetary union DSGE model, accounting for borrowing constraints of entrepreneurs and impatient households and an internal constraint on the bank's leverage ratio. We illustrate in particular how rule-of-thumb lending standards based on the macroeconomic performance of the core region within the monetary union can translate into destabilizing spill-over effects into the other region, resulting in an overall higher macroeconomic volatility. Thereby, we demonstrate a channel through which the financial sector may have exacerbated the emergence of macroeconomic imbalances within the EMU. This effect may be mitigated by macroprudential policies, where especially policies that force the bank's lending standards to be less procyclical prove to be effective in stabilizing output in both regions of the monetary union.
\end{abstract}

Keywords: Cross-Border Banking, Euro Area, Monetary Unions, DSGE, Macroprudential Policies

\section{INTRODUCTION}

Understanding the transmission mechanisms and macroeconomic consequences of cross-border banking has become a central importance for global financial and macroeconomic stability. Indeed, while foreign direct investment (FDI) and equity portfolio investment (EPI) are conducive to increased international risk sharing

\footnotetext{
We thank the associate editor and two anonymous referees, as well as Zeno Enders, Philipp Engler, Mathias Hoffmann, Angela Abbate, Alexander Meyer-Gohde, Michael Paetz, and Henning Weber for helpful comments and suggestions. The authors also thank Philipp Engler, Federico Signoretti, and Andrea Gerali for sharing their code and Julia Lipp for excellent research assistance. This is a significantly revised version of Dräger and Proaño (2015). Part of this research was conducted while Christian R. Proaño was visiting the Research Centre of the Deutsche Bundesbank, the hospitality of which is gratefully acknowledged. The views expressed in this paper do not necessarily reflect those of the Deutsche Bundesbank. Financial support by the Hans-Böckler Foundation is gratefully acknowledged. Address correspondence to: Lena Dräger, Leibniz Universität Hannover, Königsworther Platz 1, D-30167 Hannover, Germany; e-mail: draeger@gif.uni-hannover.de.
} 
and may thus contribute to higher macrofinancial stability, bank-related crossborder flows are more procyclical and volatile, especially in adverse economic situations when sharp reversals of capital flows and reserve adjustments may occur, as discussed in CIEPR (2012).

Given the well-known predominance of the banking sector in the European financial landscape, where the expansion in cross-border financial activities over the last 20 years took place primarily in the form of bank-related capital flows, these issues are of central importance for the European Monetary Union (EMU) [BIS (2010), Kleimeier et al. (2013)]. The macroeconomic effects of increased cross-border financial flows in the EMU in recent times have been ambiguous. While initially the increased cross-border flows may have supported economic convergence processes within EMU, cross-border banking was a driving factor also for the credit booms and housing bubbles in some European countries such as Spain and Ireland, and thereby contributed to the build-up of destabilizing intra-EMU current account imbalances [see, e.g., Allen et al. (2011), BIS (2011), and Gnimassoun and Mignon (2016)]. Further, as European banks had an unexpectedly large exposure to the U.S. securitized asset markets on the onset of the 2007-2009 global financial crisis, they played a central role in its accruement and propagation from the United States to the European continent [Borio and Disyatat (2011)].

Against this background, in this paper, we investigate the role of cross-border bank credit flows in a two-region monetary union by incorporating a union-wide banking sector in an otherwise standard two-country DSGE framework. Our model defines a financially constrained union-wide bank with national retail branches in each region of the monetary union, where cross-border banking constitutes the allocation of loans to credit-constrained firms and households in each region. As the main contribution of the paper, we evaluate the macroeconomic consequences of cross-border banking under alternative lending standards in a core and a periphery region, and evaluate the impact of different macroprudential policies on macroeconomic stability.

Based on recent empirical evidence from the ECB's bank lending survey (BLS), which suggests that lending standards in the Euro area have been procyclical in recent times [Cihák and Brooks (2009)], we assume that the union-wide bank suffers from asymmetric information and thus sets its lending standards, measured by households' and firms' required loan-to-value (LTV) ratio in each region, on the basis of the region's last period output gap. We contrast this scenario with an alternative rule-of-thumb scenario where the global bank sets a uniform lending standard for both regions on the basis of the last period output gap in the core region. The motivation for this alternative heuristic is the observation of a convergence in lending standards at the beginning of EMU, where financial markets applied the low risk premia of core economies also to the periphery. Our model thus allows to evaluate the role of financial integration in the transmission and amplification of shocks throughout the monetary union through the lens of a bounded rationality environment. Throughout the paper, we define the core of the EMU to consist 
of Germany, France, the Netherlands, Finland, Belgium, and Austria, and the periphery to include Spain, Greece, Portugal, Ireland, and Italy. ${ }^{1}$

Without aiming to deliver a complete explanation for the sizeable capital inflows into some of the periphery countries of the EMU, this latter scenario is intended to capture the effect of convergence of credit conditions at the start of the European monetary union. This is illustrated in Figure 1, where we illustrate banks' subjective and qualitative assessment of the changes in their lending behavior and in credit conditions asked from both enterprises and households as collected in the ECB's BLS. Banks' qualitative survey answers are collected in diffusion indices that give the difference between the weighted sum of the percentage of banks stating that conditions have tightened and those stating that conditions have eased. ${ }^{2}$ We aggregate country-specific diffusion indices across our definition of the core and the periphery regions of EMU in order to visualize both the procyclicality of lending conditions and the convergence across EMU member states. ${ }^{3}$

The graphs in Figure 1 show that lending conditions in the early years of EMU became easier as more banks gave answers indicating they were less strict in their credit standards, shown by falling diffusion indices. At the same time, we observe a convergence in lending conditions between the core and the periphery region. This pattern applies both to credit standards in general, and to collateral requirements demanded from enterprises as well as LTV ratios demanded for household mortgages. As can also be clearly observed, in 2008, at the start of the recession following the global financial crisis as well as in 2011 at the start of the recession due to the European sovereign debt crisis, EMU banks tightened credit standards sharply, especially in the periphery region. Conversely, in nonrecessionary or expansionary periods, we observe a loosening in credit standards. Overall, this indicates that banks in the EMU have indeed used procyclical lending standards in recent decades and that the convergence in risk premia at the start of EMU was also reflected in lending standards in general.

Calibrating the model to the EMU, we evaluate the nature of cross-border banking and trading flows in a monetary union with different LTV-based lending standards. In the baseline scenario, bank's desired LTV ratio of firms is assumed to be constant and equal across regions. The baseline scenario may thus be regarded as capturing the case with symmetric information regarding firms' and households' net worth in both regions. In the second scenario, the LTV ratio is driven by the region-specific previous output gaps. Thereby, a positive economic situation not only affects firms' net worth directly, but also serves as a signal for banks' assessment of firms' creditworthiness, resulting in procyclical lending standards. In the third scenario, we assume that there exists one dominating core region providing the signal for creditworthiness across the whole monetary union. This scenario may be regarded as capturing the convergence in risk-premia across EMU countries with the introduction of the common currency. We evaluate the impact of regional technology shocks and discount factor shocks across the three scenarios.

In a nutshell, our simulation results highlight the role of cross-border lending under asymmetric information not only as an amplifying mechanism within a 

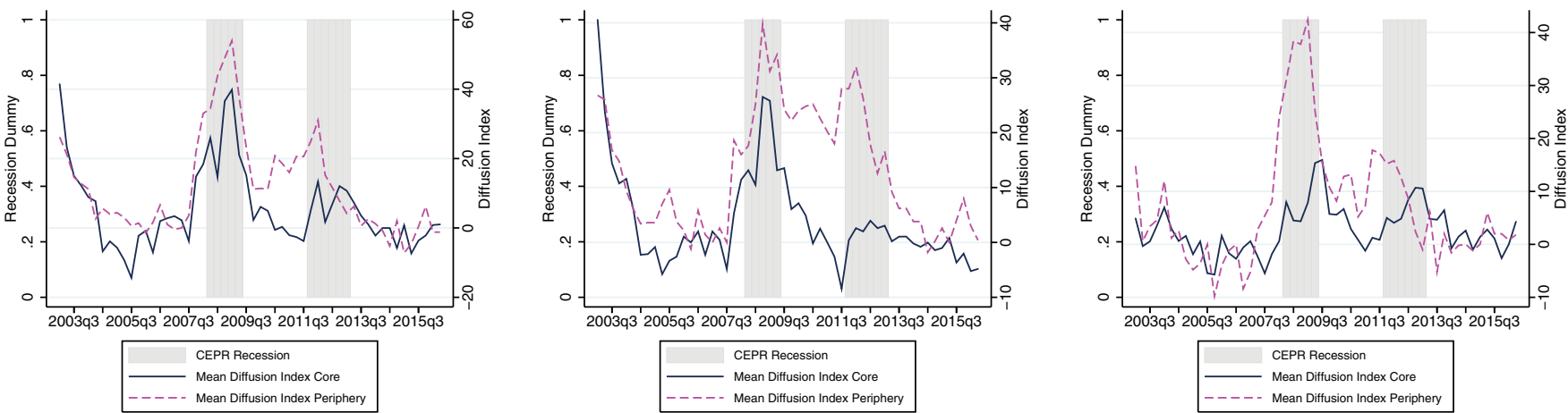

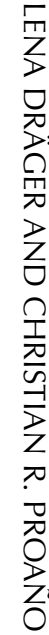

FIGURE 1. Diffusion indices of qualitative changes in credit standards, collateral requirements for loans to enterprises, and LTV ratios for household mortgages. Source: ECB bank lending survey. (a) Credit standards. (b) Collateral requirements. (c) LTV ratios for mortgages. 
monetary union, but also as a potential source of macroeconomic instability. More precisely, while cross-border lending amplifies the effects of exogenous shocks in all three considered scenarios, in the latter one-where there is a core region which implicitly determines the lending standards for the whole monetary union-unified lending standards lead to the occurrence of business fluctuations in the periphery region driven purely by laxer credit conditions, and not by macroeconomic fundamentals. Hence, the financial sector may work to exacerbate the emergence of macroeconomic imbalances in a monetary union if banks assign lending standards from one core region to the whole monetary union. Some of these destabilizing effects can be mitigated by macroprudential policies as shown in four policy experiments. Especially policies that aim at forcing the bank's lending standards to be less procyclical are effective in reducing output volatility, while policies that restrict the bank's leverage ratio stabilize the leverage position and also to some extent reduce output volatility in both regions.

In modern DSGE models, the banking sector has only recently received more attention. While models accounting for a financial accelerator as in Bernanke et al. (1999) or Iacoviello (2005) are now relatively common, most models do not feature a detailed banking sector. Gerali et al. (2010) set up a DSGE model with an imperfectly competitive banking sector subject to an internal leverage constraint and entrepreneurs facing a borrowing constraint. Estimating the model on Euro area data, the authors report that shocks originating in the banking sector explain the largest share of the contraction of economic activity in 2008, while macroeconomic shocks play only a limited role. A similar result is obtained in Kollmann et al. (2011) in an estimated two-country model for the United States and the Euro area as well as in the empirical study by Kalemli-Ozcan et al. (2013). In a simplified version of the model by Gerali et al. (2010), Gambacorta and Signoretti (2014) analyze whether monetary policy should also target asset prices or credit in the presence of borrowing constraints on firms' side and a banking sector with a credit supply constraint. They show that leaning-against-the-wind policies by the central bank in reaction to supply side shocks allow for a better trade-off between output and inflation stabilization. Hence, the authors reinforce the results obtained by Cúrdia and Woodford (2010) in a much simpler model with exogenously introduced interest rate spreads. In the theoretical model of this paper, we build on the work of Gerali et al. (2010) and Gambacorta and Signoretti (2014) to evaluate the effect of borrowing and credit supply constraints in a tworegion monetary union, focusing on spill-over effects of changes in cross-border lending standards between the regions and the effects of macroprudential policies.

Our analysis relates to both the empirical and the theoretical literature on the relationship between bank lending conditions, macroeconomic outcomes, and monetary policy. Evidence that lending conditions in the EMU tend to be procyclical is provided in Cihák and Brooks (2009) and CIEPR (2012). Maddaloni and Peydrò (2013) estimate GLS panel regressions using the ECB's BLS to evaluate the relationship between monetary policy rates and bank lending standards before and after the 2008 financial crisis. The authors report evidence of a softening in lending conditions due to the expansive monetary policy during the crisis and suggestive 
evidence of excessive risk-taking for mortgage loans before the crisis. In a twocountry DSGE model with financial frictions, Gruss and Sgherri (2009) define LTV ratios as an AR process with a shock component and show that changes in financial conditions account for a large portion of variation in real GDP. Similarly, Gerali et al. (2010) report that shocks to LTV ratios demanded from firms can explain a large share of both the expansion before and the contraction during the recent financial crisis. Finally, Hristov et al. (2014) estimate panel VAR models with sign restrictions to evaluate interest rate pass-through during the crisis. The authors show that the decrease in pass-through is related to an increase in banking frictions in the DSGE model of Gerali et al. (2010). Our approach extends this literature by capturing the procyclicality in LTV ratios as we explicitly relate bank's lending standards to the evolution of the business cycle.

Moreover, our paper is related to the models with cross-border banking and global banks in Ueda (2012), Kalemli-Ozcan et al. (2013), Kamber and Thoenissen (2013), in 't Veld et al. (2014), and Poutineau and Vermandel (2015). Both Ueda (2012) and Kalemli-Ozcan et al. (2013) focus on the effect of real and financial shocks in two-country DSGE models with financially constrained national banks or a global bank, respectively, and report that financial shocks may cause an international synchronization of business cycles. The three-country New Keynesian model analyzed in in 't Veld et al. (2014) analyzes the emergence of international capital flows in a monetary union like the EMU. More related to our approach, Kamber and Thoenissen (2013) incorporate a banking sector à la Gerali et al. (2010) into an international RBC model of a small open economy. The authors assume that banks in the small open home economy extend loans also to firms in the large foreign economy, and show that the propagation of foreign financial shocks to the home economy depends on the degree of financial integration of the domestic banking sector. Similarly, Poutineau and Vermandel (2015) investigate cross-border financial flows in an estimated DSGE model of a currency union with a core and a periphery region. In line with our results, the authors demonstrate that cross-border flows provide a channel through which asymmetric shocks may diffuse throughout the monetary union, thereby increasing the sensitivity of real variables to financial shocks. All of these previous approaches differ from ours in that we model cross-border lending via the specification of a financially constrained union-wide bank with loan retail branches at the national level, and analyze the effects of changes in the banks' lending standards across the monetary union.

The policy analysis of this paper focuses on the effects of macroprudential policies in our model framework. The previous literature discusses several macroprudential instruments, such as LTV caps, debt-to-income caps, or levies on noncore liabilities [Allen et al. (2011), CIEPR (2012)]. Previous theoretical analyses such as Lambertini et al. (2013), Quint and Rabanal (2014), and Brzoza-Brzezina et al. (2015) focus on policies that force the LTV ratio to be countercyclical or that limit the fraction of liabilities the bank can lend. The studies evaluate welfare effects for borrowers and savers or for core and periphery regions, respectively. Evaluating the impact of asymmetric shocks on the core and the periphery, Brzoza-Brzezina et al. 
(2015) show that macroprudential policy can reduce macroeconomic volatility if it is decentralized in each region. Lambertini et al. (2013) and Quint and Rabanal (2014) provide evidence that particularly savers benefit from macroprudential policies. We add to this literature by evaluating a range of macroprudential policy instruments with different scenarios for the evolution of banks' lending conditions across the regions.

Finally, our approach is more broadly related to other DSGE models of a monetary union, such as Benigno (2004), Galí and Monacelli (2008), Beetsma and Jensen (2005), Duarte and Wolman (2008), Ferrero (2009), and Engler et al. (2017). While the former three papers evaluate optimal monetary and fiscal policy rules in a monetary union, the latter three papers focus more specifically on problems related to fiscal policy in a monetary union, such as possibilities to improve inflation differentials with fiscal policy, or to use fiscal devaluation to counteract macroeconomic imbalances.

The remainder of this paper is organized as follows: In Section 2, we set up a two-region DSGE model of a monetary union with a cross-border banking sector consisting of an international wholesale branch and region-specific retail branches as in Gerali et al. (2010) and Gambacorta and Signoretti (2014). In Section 3, we analyze the dynamic adjustments of the model's main variables to unexpected regional technology and discount factor shocks, as well as the consequences of alternative specifications of the lending standards by the banking sector. Moreover, we present the results of four different macroprudential policy experiments. Finally, we draw some concluding remarks in Section 4.

\section{THE MODEL}

We consider a two-region monetary union populated by a continuum of agents on the interval $[0,1]$, a segment $[0, n]$ residing in a region labeled $H$ (the periphery), and the other segment living in the other region labeled $F$ (the core). We assume that the periphery $H$ is the risky region, and the core $F$ is the safe-haven region. There is no labor mobility between the regions. ${ }^{4}$ Both regions are assumed to produce tradable consumption goods, which are considered to be imperfect substitutes due to a standard home bias argument. Since we model a monetary union, the nominal exchange rate between the regions is constant and may be normalized to one. Throughout this section, notation is generally given for the periphery region $H$, where analogous relationships apply for the core region $F$, unless otherwise stated.

\subsection{Households}

Households in both regions are infinitely lived and have identical preferences and endowments within each region. Further, as in Iacoviello (2005), we assume that there exist both patient and impatient households in both regions. Because it is assumed that impatient households have a lower discount factor than patient households $\left(\beta_{i}<\beta_{p}\right)$, in equilibrium patient households save via deposits at 
banks and impatient households borrow in the form of loans from banks. Note that our assumption of a lower discount factor for impatient households ensures that the borrowing constraint will always bind in the neighborhood of the steady state. Patient households are assumed to earn the same interest on their deposits throughout the monetary union, which equals the risk-free monetary policy rate. Impatient households are subject to a borrowing constraint depending on their stock of housing collateral and the LTV ratio that banks demand. Households maximize utility, which we assume to be separable in consumption, housing, and leisure. In order to render the model stationary, we follow Schmitt-Grohé and Uribe (2003) and assume that households face a small quadratic portfolio adjustment $\operatorname{cost} \theta^{D}$ when their deposits differ from the steady-state level $\bar{D}$.

All households receive utility from consumption and housing services and disutility from working. Additionally, we assume that patient households may be subject to a stochastic shock that affects their discount rate.

Following Duarte and Wolman (2008) and Ferrero (2009), the aggregate consumption bundle consumed by households in the periphery $H$ contains regionspecific goods bundles from both regions and is defined as

$$
\begin{aligned}
C_{t}^{\mathrm{HH}} & =\gamma_{p} C_{t}^{p H}+\gamma_{i} C_{t}^{i H} \\
& =\left[\left(1-\omega^{H}\right)^{1 / \sigma}\left(C_{t}^{h}\right)^{\sigma-1 / \sigma}+\left(\omega^{H}\right)^{1 / \sigma}\left(C_{t}^{f}\right)^{\sigma-1 / \sigma}\right]^{\sigma / \sigma-1},
\end{aligned}
$$

where $\gamma_{p}$ and $\gamma_{i}$ denote the shares of patient and impatient households, $C_{t}^{h}$ and $C_{t}^{f}$ represent bundles of retail consumption goods $i$ produced in $H$ and $F$, respectively, $\sigma$ denotes the elasticity of substitution between these two consumption bundles, and the parameter $\omega^{H}$ represents the steady-state import share of households in $H$. Given our assumption of home bias in consumption, it holds that $\omega^{H}<(1-n) .^{5}$

Assuming that the law of one price holds and fixing the nominal exchange rate at one, retail prices for individual goods will be the same in both regions: $P_{t}^{h}(i)=P_{t}^{h *}(i)$ and $P_{t}^{f}(i)=P_{t}^{f *}(i)$, where $P_{t}^{h *}(i)$ and $P_{t}^{f *}(i)$ are the prices of goods $Y_{t}^{h}(i)$ and $Y_{t}^{f}(i)$ in the other region, respectively. From the demand functions for individual goods and defining the terms of trade as the price index of goods produced in $F$ relative to that of goods produced in $H, T_{t} \equiv P_{t}^{f} / P_{t}^{h}$, it is straightforward to derive expressions for relative prices in $H$ and $F$, and the resulting real exchange rate:

$$
\operatorname{RER}_{t}=\frac{P_{t}^{F}}{P_{t}^{H}}=T_{t}\left[\frac{\left(1-\omega^{F}\right)+\omega^{F} T_{t}^{\sigma-1}}{\left(1-\omega^{H}\right)+\omega^{H} T^{1-\sigma}}\right]^{1 / 1-\sigma}
$$

where $P_{t}^{H} \equiv\left[\left(1-\omega^{H}\right)\left(P_{t}^{h}\right)^{1-\sigma}+\omega^{H}\left(P_{t}^{f}\right)^{1-\sigma}\right]^{1 / 1-\sigma}$ denotes the CPI price index in $H$ and accordingly for $F$. 
Moreover, we can relate the domestic retail inflation $\pi_{t}^{h}$ and $\pi_{t}^{f}$ to CPI inflation in the respective regions, defined as $\pi_{t}^{H} \equiv P_{t}^{H} / P_{t-1}^{H}$ and $\pi_{t}^{F} \equiv P_{t}^{F} / P_{t-1}^{F}$ :

$$
\begin{aligned}
& \pi_{t}^{H}=\pi_{t}^{h}\left[\frac{\left(1-\omega^{H}\right)+\omega^{H} T_{t}^{1-\sigma}}{\left(1-\omega^{H}\right)+\omega^{H} T_{t-1}^{1-\sigma}}\right]^{1 / 1-\sigma}, \\
& \pi_{t}^{F}=\pi_{t}^{f}\left[\frac{\left(1-\omega^{F}\right)+\omega^{F} T_{t}^{\sigma-1}}{\left(1-\omega^{F}\right)+\omega^{F} T_{t-1}^{\sigma-1}}\right]^{1 / 1-\sigma} .
\end{aligned}
$$

Patient households. In a standard manner, the utility maximization problem of patient households in the periphery $H$ is given by

$$
\begin{aligned}
\max & E_{0}\left\{\sum_{t=0}^{\infty} \beta_{p}^{t}\left(\prod_{j=0}^{t} \vartheta_{j-1}^{S H}\right)\right. \\
& \left.\times\left[\left(1-a_{p}\right) \ln \left(C_{t}^{p H}-a_{p} C_{t-1}^{p H}\right)+j \ln H_{t}^{p H}-\frac{\left(N_{t}^{p H}\right)^{\eta+1}}{\eta+1}\right]\right\}
\end{aligned}
$$

subject to the real budget constraint

$$
\begin{gathered}
C_{t}^{p H}+q_{t}^{H H}\left(H_{t}^{p H}-H_{t-1}^{p H}\right)+D_{t}^{p H}=\left(\frac{W_{t}^{p H}}{P_{t}^{H}}\right) N_{t}^{p H} \\
+\frac{\left(1+r_{t-1}^{d}\right) D_{t-1}^{p H}}{\pi_{t}^{H}}+\frac{\theta_{D}}{2}\left(D_{t}^{p H}-\bar{D}\right)^{2}+\frac{\Pi_{t}^{p H}}{\gamma_{p}}
\end{gathered}
$$

where $H_{t}^{p H}$ is the stock of housing of patient households in $H$ with real price $q_{t}^{H H}, N_{t}^{p H}$ is the patient households' labor supply in $H, D_{t}^{p H}$ are deposits earning interest $r_{t}^{d}, \pi_{t}^{H} \equiv P_{t}^{H} / P_{t-1}^{H}$ is the gross CPI inflation rate in $H,\left(W_{t}^{p H} / P_{t}^{H}\right)$ is the real wage, and $\Pi_{t}^{H}$ denotes real profits from retailers in $H$, which are paid lump-sum to patient households. The parameter $a_{p}$ measures the degree of habit persistence of patient households, the share of patient households in the economy is denoted by $\gamma_{p}$, and $\vartheta^{S H}$ describes the stochastic discount factor shock which is assumed to follow an exogenous $\mathrm{AR}(1)$ process with persistence parameter $\rho_{s}$ and i.i.d. shock process $\varepsilon_{t}^{S H}$. Note that the discount factor shock is assumed to be realized at the end of the period, so that it affects the discount factor in the following period. Households then maximize the expected present discounted value of intertemporal utility, which we assume to be separable in consumption, housing and leisure.

From the FOCs of this intertemporal optimization problem, we obtain the standard labor supply equation, a housing demand function and a consumption 


\section{4}

Euler equation for patient households:

$$
\begin{gathered}
\left(N_{t}^{p H}\right)^{\eta}=\frac{W_{t}^{p H}}{P_{t}^{H}} \frac{\left(1-a_{p}\right)}{C_{t}^{p H}-a_{p} C_{t-1}^{p H}}, \\
\frac{j}{H_{t}^{p H}}+E_{t}\left[\frac{\left(1-a_{p}\right) \beta_{p} \vartheta_{t}^{S H} q_{t+1}^{H H}}{C_{t+1}^{p H}-a_{p} C_{t}^{p H}}\right]=\frac{\left(1-a_{p}\right) q_{t}^{H H}}{C_{t}^{p H}-a_{p} C_{t-1}^{p H}}, \\
\frac{\left(1-a_{p}\right)\left[1-\theta_{D}\left(D_{t}^{p H}-\bar{D}\right)\right]}{C_{t}^{p H}-a_{p} C_{t-1}^{p H}}=E_{t}\left[\frac{\left(1-a_{p}\right) \beta_{p} \vartheta_{t}^{S H}\left(1+r_{t}^{d}\right)}{\left(C_{t+1}^{p H}-a_{p} C_{t}^{p H}\right) \pi_{t+1}^{H}}\right] .
\end{gathered}
$$

Impatient households. Impatient households have a stronger preference for current consumption, and therefore borrow in equilibrium. In line with Iacoviello (2005), they are assumed to be constrained in their borrowing. This gives the following utility maximization problem of impatient households in $H$ :

$$
\max E_{0}\left\{\sum_{t=0}^{\infty} \beta_{i}^{t}\left[\left(1-a_{i}\right) \ln \left(C_{t}^{i H}-a_{i} C_{t-1}^{i H}\right)+j \ln H_{t}^{i H}-\frac{\left(N_{t}^{i H}\right)^{\eta+1}}{\eta+1}\right]\right\}
$$

subject to the real budget constraint

$$
C_{t}^{i H}+q_{t}^{H H}\left(H_{t}^{i H}-H_{t-1}^{i H}\right)+\frac{1+r_{t-1}^{b H}}{\pi_{t}^{H}} B_{t-1}^{i H}=\left(\frac{W_{t}^{i H}}{P_{t}^{H}}\right) N_{t}^{i H}+B_{t}^{i H},
$$

and the borrowing constraint

$$
B_{t}^{i H} \leq \frac{m_{t}^{i H} E_{t}\left(q_{t+1}^{H H} H_{t}^{i H} \pi_{t+1}^{H}\right)}{1+r_{t}^{b H}}
$$

where $B_{t}^{i H}$ denotes the amount of loans ${ }^{7}$ borrowed by impatient households at the loan rate $r_{t}^{b H}$ and $m_{t}^{i H}$ is the LTV ratio that banks demand of impatient households. As is usual in the mortgage market, the LTV ratio gives the fraction that impatient households may borrow against their housing collateral.

This yields the adjusted labor supply, housing demand, and consumption Euler equation of impatient households:

$$
\begin{gathered}
\left(N_{t}^{i H}\right)^{\eta}=\frac{W_{t}^{i H}}{P_{t}^{H}} \frac{\left(1-a_{i}\right)}{C_{t}^{i H}-a_{i} C_{t-1}^{i H}}, \\
\frac{j}{H_{t}^{i H}}+E_{t}\left[\frac{\left(1-a_{i}\right) \beta_{i} \vartheta_{t}^{S H} q_{t+1}^{H H}}{C_{t+1}^{i H}-a_{i} C_{t}^{i H}}\right]+s_{t}^{i H} \frac{m_{t}^{i H} E_{t}\left(q_{t+1}^{H H} \pi_{t+1}^{H}\right)}{1+r_{t}^{b H}}=\frac{\left(1-a_{i}\right) q_{t}^{H H}}{C_{t}^{i H}-a_{i} C_{t-1}^{i H}},
\end{gathered}
$$




$$
E_{t}\left[\frac{\left(1-a_{p}\right) \beta_{i}\left(1+r_{t}^{b H}\right)}{\left(C_{t+1}^{i H}-a_{i} C_{t}^{i H}\right) \pi_{t+1}^{H}}\right]+s_{t}^{i H}=\frac{1-a_{i}}{C_{t}^{i H}-a_{i} C_{t-1}^{i H}}
$$

where $s_{t}^{i H}$ is the Lagrange multiplier on the borrowing constraint.

\subsection{Firms}

Production is assumed to take place in two stages. In the first stage, entrepreneurs in region $H$ and in region $F$ produce the intermediate good $Y_{t}^{h \text {,int }}$ and $Y_{t}^{f, \text { int }}$ in fully competitive markets and under credit constraints as in Iacoviello (2005). In line with Bernanke et al. (1999), we then assume that intermediate goods are sold to retailers, who take their price as given and differentiate them at no cost. Due to the differentiation of products, retailers are assumed to operate under monopolistic competition and face a quadratic cost for the adjustment of prices as in Rotemberg (1982). All profits from retail activities are rebated lump-sum to patient households in the respective region.

Entrepreneurs. Entrepreneurs in regions $H$ and $F$ produce intermediate goods $Y_{t}^{h, \text { int }}$ and $Y_{t}^{f, \text { int }}$ under perfect competition. Intermediate goods are used in the production of a final consumption good and are assumed to be nontradable. Entrepreneurs aim at maximizing their consumption and use capital goods and labor for the production of intermediate goods. We assume that entrepreneurs consume only goods from their own region. At the end of each period, entrepreneurs buy new capital goods from capital producers, so that capital is only realized in the next period. Investment into new capital goods is assumed to be financed with loans from banks, where similar to impatient households we assume that entrepreneurs have a lower discount factor than patient households. ${ }^{8}$ Following Iacoviello (2005), we assume that entrepreneurs are credit-constrained due to the risk of default on their loans and thus can only borrow up to a fraction of their collateral, i.e., their capital assets. The resulting dynamics are similar to a financial accelerator effect as in Bernanke et al. (1999). Again, the assumption of a lower discount factor $\beta_{E}$ for firms ensures that the borrowing constraint will always bind in the neighborhood of the steady state.

Entrepreneurs in $H$ thus maximize consumption $C_{t}^{\mathrm{EH}}$ under habit formation with degree $a_{e}$ and subject to their budget and their borrowing constraints and to a Cobb-Douglas constant-returns-to-scale production function:

$$
\max E_{0}\left[\sum_{t=0}^{\infty} \beta_{e}^{t}\left(1-a_{e}\right) \ln \left(C_{t}^{E H}-a_{e} C_{t-1}^{E H}\right)\right]
$$


s.t.

$$
\begin{gathered}
C_{t}^{E H}+\frac{\left(1+r_{t-1}^{b H}\right)}{\pi_{t}^{H}} B_{t-1}^{E H}+\left(\frac{W_{t}^{p H}}{P_{t}^{H}}\right) N_{t}^{d p H}+\left(\frac{W_{t}^{i H}}{P_{t}^{H}}\right) N_{t}^{d i H}+q_{t}^{K H} K_{t}^{H} \\
\leq \frac{Y_{t}^{h, \text { int }}}{\mu_{t}^{H}}+B_{t}^{E H}+q_{t}^{k H}\left(1-\delta^{k}\right) K_{t-1}^{E H}, s s \\
B_{t}^{E H} \leq \frac{m_{t}^{E H} E_{t}\left[q_{t+1}^{k H}\left(1-\delta^{k}\right) K_{t}^{E H} \pi_{t+1}^{H}\right]}{1+r_{t}^{b H}} \\
Y_{t}^{h, \text { int }}=A_{t}^{H}\left(K_{t-1}^{E H}\right)^{\alpha}\left[\left(N_{t}^{d p H}\right)^{\xi}\left(N_{t}^{d i H}\right)^{(1-\xi)}\right]^{(1-\alpha)}
\end{gathered}
$$

where $C_{t}^{E H}$ is entrepreneurs' consumption in $H, B_{t}^{E H}$ is the amount borrowed from banks at the loan rate $\left(1+r_{t}^{b H}\right), N_{t}^{d p H}$ and $N_{t}^{d i H}$ are the amounts of labor from patient and impatient households demanded by entrepreneurs at the respective wages $W_{t}^{p H}$ and $W_{t}^{i H}, \mu_{t}^{H} \equiv P_{h, t} / P_{t}^{h, i n t}$ denotes the markup of retail over intermediate goods prices, $K_{t}^{E H}$ is capital obtained at the price $q_{t}^{k H}$ and depreciated with rate $\delta^{k}$. The Cobb-Douglas production function gives output as a function of capital and labor inputs, $\alpha$ is the capital share, $\xi$ is the labor share of patient households, and $A_{t}^{H}$ is an exogenous technology process which may differ across regions. We define $A_{t}^{H}$ as an exogenous $\mathrm{AR}(1)$ process with persistence parameter $\rho_{a}$ and i.i.d. shock process $\varepsilon_{t}^{A H}$.

The borrowing constraint in (18) states that loans cannot exceed a fraction $m_{t}^{E H}$ of the real depreciated value of capital assets in relation to the interest obligations, in order to mitigate potential losses from loan default as in the seminal financial accelerator model by Bernanke et al. (1999). Hence, $m_{t}^{E H}$ may be interpreted as the LTV ratio that banks demand of entrepreneurs and, thus, gives a measure of banks' assessment regarding firms' creditworthiness.

Defining the real return of capital as $R_{t}^{k H} \equiv \frac{\alpha A_{t}^{H}\left(K_{t-1}^{E H}\right)^{\alpha-1}\left[\left(N_{t}^{d p H}\right)^{\xi}\left(N_{t}^{d i H}\right)^{(1-\xi)}\right]^{(1-\alpha)}}{\mu_{t}^{H}}$, we then get the following optimality conditions:

$$
\begin{gathered}
\frac{1-a_{e}}{C_{t}^{E H}-a_{e} C_{t-1}^{E H}}=E_{t}\left[\frac{\left(1-a_{e}\right) \beta_{e}\left(1+r_{t}^{b H}\right)}{\left(C_{t+1}^{E H}-a_{e} C_{t}^{E H}\right) \pi_{t+1}^{H}}\right]+s_{t}^{E H}, \\
\frac{\left(1-a_{e}\right) q_{t}^{K H}}{C_{t}^{E H}-a_{e} C_{t-1}^{E H}}=E_{t}\left\{\frac{\left(1-a_{e}\right) \beta_{e}\left[R_{t+1}^{k H}+q_{t+1}^{k H}\left(1-\delta^{k}\right)\right]}{C_{t+1}^{E H}-a_{e} C_{t}^{E H}}\right\} \\
+s_{t}^{E H} \frac{m_{t}^{E H} E_{t}\left[q_{t+1}^{k H}\left(1-\delta^{k}\right) \pi_{t+1}^{H}\right]}{1+r_{t}^{b H}},
\end{gathered}
$$




$$
\begin{aligned}
\frac{W_{t}^{p H}}{P_{t}^{H}} & =\frac{\xi(1-\alpha) Y_{t}^{h, \text { int }}}{N_{t}^{d p H} \mu_{t}^{H}}, \\
\frac{W_{t}^{i H}}{P_{t}^{H}} & =\frac{(1-\xi)(1-\alpha) Y_{t}^{h, \text { int }}}{N_{t}^{d i H} \mu_{t}^{H}} .
\end{aligned}
$$

Equation (20) describes the entrepreneurs' Euler equation, where $s_{t}^{E H}$ denotes the Lagrange multiplier on the borrowing constraint and thus gives the marginal value of one unit of borrowing. The relation in (21) gives the optimal relation between entrepreneurs' consumption and real returns from capital, given the borrowing constraint. Finally, equations (22) and (23) show that in the optimum, real wages equal the marginal product of labor of each household type.

Capital producers. As in Gerali et al. (2010) and Gambacorta and Signoretti (2014), we assume that each period, capital production is undertaken by perfectly competitive capital producers, which are owned by entrepreneurs. These firms buy last period's depreciated capital stock from entrepreneurs as well as an investment $I_{t}$ in the form of new final goods from retailers and use both to produce the new capital stock. In line with previous authors, we assume that old capital stock can be transformed one-for-one into new capital stock, while investment from final goods underlies a quadratic adjustment cost for the transformation into capital goods. At the end of the period, the resulting new capital stock is sold back to entrepreneurs.

Defining $\Delta \bar{x}_{t}^{H} \equiv K_{t}^{E H}-\left(1-\delta^{k}\right) K_{t-1}^{E H}$, capital goods producers in $H$ then solve the following problem:

$$
\max _{\Delta \bar{x}_{t}^{H}, I_{t}^{H}} E_{0} \sum_{t=0}^{\infty} \Lambda_{k, t}^{E H}\left(q_{t}^{k H} \Delta \bar{x}_{t}^{H}-I_{t}^{H}\right),
$$

s.t.

$$
\Delta \bar{x}_{t}^{H}=\left[1-\frac{\kappa^{I}}{2}\left(\frac{I_{t}^{H}}{I_{t-1}^{H}}-1\right)^{2}\right] I_{t}^{H},
$$

where $\Lambda_{k, t}^{E H} \equiv \beta_{e}^{k} U^{\prime}\left(C_{t+k}^{E H}\right)=\beta_{e}^{k} \lambda_{t+k}^{E H}$, with $k=0,1, \ldots$, is the stochastic discount factor from entrepreneurs, which are assumed to own capital producing firms, and $\lambda_{t}^{E H}$ is the Lagrange multiplier on entrepreneur's budget constraint. The capital adjustment cost is denoted by $\kappa^{I}$, which we assume to be equal across regions. The FOCs then yield an expression determining the price of real capital, $q_{t}^{k H}$ :

$$
\begin{aligned}
1 & =q_{t}^{k H}\left[1-\frac{\kappa^{I}}{2}\left(\frac{I_{t}^{H}}{I_{t-1}^{H}}-1\right)^{2}-\kappa^{I}\left(\frac{I_{t}^{H}}{I_{t-1}^{H}}-1\right) \frac{I_{t}^{H}}{I_{t-1}^{H}}\right] \\
& +\beta_{e} E_{t}\left[\frac{\lambda_{t+1}^{E H}}{\lambda_{t}^{E H}} q_{t+1}^{k H} \kappa^{I}\left(\frac{I_{t+1}^{H}}{I_{t}^{H}}-1\right)\left(\frac{I_{t+1}^{H}}{I_{t}^{H}}\right)^{2}\right] .
\end{aligned}
$$


Retailers. $\quad$ Retailers in regions $H$ and $F$ buy intermediate goods $Y_{t}^{h \text {,int }}$ or $Y_{t}^{f \text {,int }}$ from entrepreneurs in a competitive market, taking their price $P_{t}^{h \text {,int }}$ or $P_{t}^{f \text {,int }}$ as given. These intermediate goods are then differentiated into final consumption goods at no cost, so that retailers operate under monopolistic competition. Additionally, they are assumed to face quadratic costs for the adjustment of prices as in Rotemberg (1982). In our two-region model, retailers are symmetric, but face the demand from consumers in both the regions as well as from the entrepreneurs of their own region.

Aggregating over households and entrepreneurs, world demand for individual retail goods for retailers in $H$ is then derived from the demand equations of households and from entrepreneurs, measured in units per domestic firm. Note that we model the elasticity of substitution for individual goods produced in $H$ as a region-specific exogenous process $\varepsilon_{t}^{H}$. This gives the total demand for individual good $Y_{t}^{h \text {,total }}(i)$, faced by a retailer in $H$ :

$$
\begin{aligned}
& Y_{t}^{h, \text { total }}(i)=\left[\frac{P_{t}^{h}(i)}{P_{t}^{h}}\right]^{-\varepsilon_{t}^{H}}\left[\left(1-\omega^{H}\right)\left(\frac{P_{t}^{h}}{P_{t}^{H}}\right)^{-\sigma}\left(\gamma_{p} C_{t}^{p H}+\gamma_{i} C_{t}^{i H}\right)\right. \\
& \left.+\omega^{F} \frac{1-n}{n}\left(\frac{P_{t}^{h}}{P_{t}^{F}}\right)^{-\sigma}\left(\gamma_{p} C_{t}^{p F}+\gamma_{i} C_{t}^{i F}\right)+\gamma_{e} C_{t}^{E H}\right], \\
& Y_{t}^{h, \text { total }}(i)=\left[\frac{P_{t}^{h}(i)}{P_{t}^{h}}\right]^{-\varepsilon_{t}^{H}} C_{t}^{W H},
\end{aligned}
$$

where $C_{t}^{W H}$ denotes aggregate world demand for retail goods from region $H$, with $\gamma_{i}$ and $\gamma_{e}$ denoting the shares of impatient households and entrepreneurs in the economy. Similarly, the expression for world demand for goods produced in the core $F$ is given by

$$
\begin{aligned}
& Y_{t}^{f, \text { total }}(i)=\left[\frac{P_{t}^{f}(i)}{P_{t}^{f}}\right]^{-\varepsilon_{t}^{F}}\left[\omega^{H} \frac{n}{1-n}\left(\frac{P_{t}^{f}}{P_{t}^{H}}\right)^{-\sigma}\left(\gamma_{p} C_{t}^{p H}+\gamma_{i} C_{t}^{i H}\right)\right. \\
& \left.+\left(1-\omega^{F}\right)\left(\frac{P_{t}^{f}}{P_{t}^{F}}\right)^{-\sigma}\left(\gamma_{p} C_{t}^{p F}+\gamma_{i} C_{t}^{i F}\right)+\gamma_{e} C_{t}^{E F}\right], \\
& Y_{t}^{f, \text { total }}(i)=\left[\frac{P_{t}^{f}(i)}{P_{t}^{f}}\right]^{-\varepsilon_{t}^{F}} C_{t}^{W F} .
\end{aligned}
$$


Moreover, we derive the trade balance from net foreign demand of tradable consumption goods by both patient and impatient households:

$$
\begin{aligned}
\mathrm{TB}_{t}^{H} & =\left[\omega^{F} \frac{1-n}{n}\left(\frac{P_{t}^{h}}{P_{t}^{F}}\right)^{-\sigma}\left(\gamma_{p} C_{t}^{p F}+\gamma_{i} C_{t}^{i F}\right)\right] \\
- & {\left[\omega^{H} \frac{n}{1-n}\left(\frac{P_{t}^{f}}{P_{t}^{H}}\right)^{-\sigma}\left(\gamma_{p} C_{t}^{p H}+\gamma_{i} C_{t}^{i H}\right)\right], } \\
\mathrm{TB}_{t}^{F} & =\left[\omega^{H} \frac{n}{1-n}\left(\frac{P_{t}^{f}}{P_{t}^{H}}\right)^{-\sigma}\left(\gamma_{p} C_{t}^{p H}+\gamma_{i} C_{t}^{i H}\right)\right] \\
- & {\left[\omega^{F} \frac{1-n}{n}\left(\frac{P_{t}^{h}}{P_{t}^{F}}\right)^{-\sigma}\left(\gamma_{p} C_{t}^{p F}+\gamma_{i} C_{t}^{i F}\right)\right] . }
\end{aligned}
$$

Individual retailers in $H$ then set the price $P_{t}^{h}(i)$ for the individual final good $Y_{t}^{h}(i)$, and thus face the following maximization problem:

$$
\begin{aligned}
\max _{P_{t}^{h}(i)} E_{t} & \sum_{t=0}^{\infty} \Lambda_{k, t}^{H H}\left\{\frac{P_{t}^{h}(i)}{P_{t}^{h}} Y_{t}^{h, \text { total }}(i)-\frac{P_{t}^{h, \text { int }}}{P_{t}^{h}} Y_{t}^{h, \text { total }}(i)\right. \\
- & \left.\frac{\kappa_{p}}{2}\left[\frac{P_{t}^{h}(i)}{P_{t-1}^{h}(i)}-1\right]^{2} C_{t}^{W H}\right\},
\end{aligned}
$$

where $\Lambda_{k, t}^{H H} \equiv \beta_{p}^{k} U^{\prime}\left(C_{t+k}^{p H}\right)=\beta_{p}^{k} \lambda_{t+k}^{H H}$, with $k=0,1, \ldots$, is the stochastic discount factor from patient households' utility maximization in $H, \pi_{t}^{h}=P_{t}^{h} / P_{t-1}^{h}$ defines retail price inflation and $\kappa_{p}$ denotes the adjustment cost for changing prices. The maximization problem is subject to total demand for the final good as derived above in (27).

Imposing a symmetric equilibrium, this yields the following optimality condition:

$$
1-\varepsilon_{t}^{H}+\frac{\varepsilon_{t}^{H}}{\mu_{t}^{H}}-\kappa_{p} \pi_{t}^{h}\left(\pi_{t}^{h}-1\right)+\beta_{p} \kappa_{p} E_{t}\left[\frac{\lambda_{t+1}^{H H}}{\lambda_{t}^{H H}} \frac{C_{t+1}^{W H}}{C_{t}^{W H}} \pi_{t+1}^{h}\left(\pi_{t+1}^{h}-1\right)\right]=0 .
$$

Finally, the exogenous process for the elasticity of substitution is related to retailers' markup shock $m k_{t}^{H}$ in region $H$ via the relation $m k_{t}^{H}=\varepsilon_{t}^{H} /\left(\varepsilon_{t}^{H}-1\right)$. We model the markup shock as an $\mathrm{AR}(1)$ process with persistence $\rho_{m k}$ and an i.i.d. shock process $\varepsilon_{t}^{m k H}$.

\subsection{The Banking Sector}

Building on the models by Gerali et al. (2010) and Gambacorta and Signoretti (2014), we assume that there exists a representative bank in the monetary union 
which consists of an union-wide wholesale branch and national retail branches in each region of the monetary union. The bank may thus be regarded as a global bank as in Kalemli-Ozcan et al. (2013) assuming that the world consists only of the monetary union. The wholesale branch decides upon credit conditions in each region by setting the lending standards of impatient households' and entrepreneurs' credit constraints as well as the loan rates and thus governs cross-border lending. In that sense, the banking sectors within the monetary union are assumed to be completely integrated.

The wholesale branch is responsible for collecting deposits from households throughout the monetary union and distributes the resulting funds to the retail branches at the internal loan rates $R^{b H}$ and $R^{b F}$. The retail branches then provide credit to entrepreneurs in their region of residence. Note that in this setup, banks cannot endogenously create new credit. The wholesale branch is additionally responsible for adhering to the exogenous constraint on the bank's leverage ratio, which is modeled in the form of a quadratic cost of deviating from the target value $v$. The value of $v$ could for instance be interpreted as reflecting regulatory legislation regarding banks' equity holdings. The credit-supply channel thus introduces an additional feedback loop between real and financial conditions in the sense that the loan rates, as well as the spread between the loan rates and the risk-free policy rate, depends on the bank's leverage, its profit and, hence, on macroeconomic conditions. Finally, retail branches in $H, F$ are assumed to operate under monopolistically competitive conditions, and thus charge a constant markup $\bar{\mu}^{b}$ on the internal loan rate $R^{b H}$, i.e., $R^{b F}$.

Aggregate deposits in the monetary union and aggregate lending to entrepreneurs and impatient households in both regions are defined as follows:

$$
\begin{aligned}
D_{t}^{H} & =\gamma_{p} D_{t}^{p H}, \\
D_{t}^{F} & =\gamma_{p} D_{t}^{p F}, \\
D_{t} & =n D_{t}^{H}+(1-n) D_{t}^{F}, \\
B_{t}^{H} & =\gamma_{i} B_{t}^{i H}+\gamma_{e} B_{t}^{E H}, \\
B_{t}^{F} & =\gamma_{i} B_{t}^{i F}+\gamma_{e} B_{t}^{E F}, \\
B_{t} & =\left[n^{\frac{1}{\gamma}}\left(B_{t}^{H}\right)^{\gamma-1 / \gamma}+(1-n)^{1 / \gamma}\left(B_{t}^{F}\right)^{\gamma-1 / \gamma}\right]^{\gamma / \gamma-1},
\end{aligned}
$$

where $\gamma_{p}, \gamma_{i}$, and $\gamma_{e}$ give the shares of patient and impatient households as well as entrepreneurs in both economies, $B_{t}^{H}$ and $B_{t}^{F}$ denote the credit supply given to retail branches in regions $H$ and $F$, respectively, and $\gamma$ denotes the bank's elasticity of substitution between lending to both regions. We thus assume that loans to the two regions are imperfect substitutes from the point of view of the bank, which may be motivated with the notion of a historically more sound economic performance in the core region, as well as with differences in the credit screening capabilities due to longer lasting borrower-lender relationships and different legal systems 
in both regions [Obstfeld and Rogoff (2001), Poutineau and Vermandel (2015)]. In our setup, the wholesale branch thus aims at maximizing profits subject to a quadratic cost for deviating from their target leverage ratio $v$ and to their budget constraint:

$$
\max n R_{t}^{b H} B_{t}^{H}+(1-n) R_{t}^{b F} B_{t}^{F}-r_{t}^{d} D_{t}-\frac{\theta}{2}\left(\frac{K_{t}^{b}}{B_{t}}-v\right)^{2} K_{t}^{b},
$$

s.t.

$$
\begin{aligned}
& B_{t}=D_{t}+K_{t}^{b}, \\
& B_{t}=\left[n^{\frac{1}{\gamma}}\left(B_{t}^{H}\right)^{\gamma-1 / \gamma}+(1-n)^{1 / \gamma}\left(B_{t}^{F}\right)^{\gamma-1 / \gamma}\right]^{\gamma / \gamma-1},
\end{aligned}
$$

where $K_{t}^{b}$ is the banks' own capital and the parameter $\theta$ gives the proportion of $K_{t}^{b}$ to which the cost of deviating from target applies. The bank's leverage ratio and its budget constraint are determined with respect to aggregate lending $B_{t}$. Solving the maximization problem gives the internal loan rates for credit supply to retail branches in regions $H$ and $F$ :

$$
\begin{aligned}
R_{t}^{b H} & =n^{1-\gamma / \gamma} r_{t}^{d}\left(\frac{B_{t}}{B_{t}^{H}}\right)^{1 / \gamma}-n^{1-\gamma / \gamma} \theta\left(\frac{K_{t}^{b}}{B_{t}}-v\right) \frac{\left(K_{t}^{b}\right)^{2}}{B_{t}^{2 \gamma+1 / \gamma}\left(B_{t}^{H}\right)^{1 / \gamma}} \\
R_{t}^{b F} & =(1-n)^{1-\gamma / \gamma} r_{t}^{d}\left(\frac{B_{t}}{B_{t}^{F}}\right)^{1 / \gamma} \\
& -(1-n)^{1-\gamma / \gamma} \theta\left(\frac{K_{t}^{b}}{B_{t}}-v\right) \frac{\left(K_{t}^{b}\right)^{2}}{B_{t}^{2 \gamma+1 / \gamma}\left(B_{t}^{F}\right)^{1 / \gamma}} .
\end{aligned}
$$

Hence, extending the closed economy setup in Gambacorta and Signoretti (2014) to the open economy case, it turns out that both the effect of the riskfree deposit rate and of the leverage constraint on the loan rate are weighted with the relative share of loan supply to the respective region, adjusted for region size. This means that loan rates in a given region will be more sensitive to deviations from the bank's leverage target and to changes in the policy rate if the wholesale branch distributes a larger share of its overall credit supply to this region.

As in Gambacorta and Signoretti (2014), the retail banks are then assumed to be able to differentiate the wholesale loans at no costs and pass them under monopolistic competition on to impatient households and entrepreneurs, charging a constant markup $\bar{\mu}^{b}$, which we assume to be equal across regions in the monetary union ${ }^{9}$ :

$$
\begin{aligned}
& r_{t}^{b H}=R_{t}^{b H}+\bar{\mu}^{b}, \\
& r_{t}^{b F}=R_{t}^{b F}+\bar{\mu}^{b} .
\end{aligned}
$$


Finally, we define aggregate banks' profits $J_{t}^{b}$ as the sum of wholesale and retail profits and assume that banks reinvest their profits into new bank capital, where a fraction $\delta^{b}$ is used each period to pay for banking activities:

$$
\begin{aligned}
J_{t}^{b} & =n r_{t}^{b H} B_{t}^{H}+(1-n) r_{t}^{b F} B_{t}^{F}-r_{t}^{d} D_{t}-\frac{\theta}{2}\left(\frac{K_{t}^{b}}{B_{t}}-v\right)^{2} K_{t}^{b}, \\
K_{t}^{b} & =\left(1-\delta^{b}\right) K_{t-1}^{b}+J_{t-1}^{b} .
\end{aligned}
$$

\subsection{Monetary Policy}

The central bank in the model controls the nominal risk-free interest rate $r_{t}^{d}$ and adjusts to inflation as in Bernanke et al. (1999). Since we model a currency union, the central bank targets inflation in both regions, where the weight is given by their relative size. This results in the following Taylor-type rule:

$$
\left(1+r_{t}^{d}\right)=\left(1+r_{t-1}^{d}\right)^{\rho}\left(1+\bar{r}^{d}\right)^{1-\rho}\left\{\left[n\left(\pi_{t}^{H}\right)+(1-n)\left(\pi_{t}^{F}\right)\right]^{\phi_{\pi}}\right\}^{1-\rho} \varepsilon_{t}^{r d},
$$

where $\rho$ measures the amount of interest rate smoothing, $\bar{r}^{d}$ the nominal steadystate interest rate, $\phi_{\pi}$ gives the strength of inflation targeting, and $\varepsilon_{t}^{r d}$ is an i.i.d. monetary policy shock.

\subsection{Asymmetric Information in the Banking Sector and Rule-of-Thumb-Based Lending}

As previously discussed [see also CIEPR (2012)], the recent experience of the housing and credit boom-and-bust cycles in Spain and Ireland-which were financed to a large extent by cross-border capital flows from Germany-seems to suggest that global cross-border lending may not have been subject to the same screening standards for creditworthiness as internal lending, and that this practice may have thus contributed decisively to the recent macroeconomic instability of those countries. Part of this behavior may be due to asymmetric information on the part of banks regarding their borrowers' true creditworthiness, which may be exacerbated in global lending.

In addition to problems related to asymmetric information, countries within the Euro area seem to have been subject to a perception of the financial sector that upon entering into the EMU, the riskiness of loans in all regions was reduced to that of the core region as could be witnessed with the reduction in loan spreads between the core and the periphery of the EMU. Hence, banks and other members of the financial market applied a simple heuristic when assessing the creditworthiness of borrowers throughout the monetary union.

In our model, the union-wide bank uses the LTV ratios demanded from both impatient households and entrepreneurs to measure its assessment of their creditworthiness. In order to capture the mechanisms regarding asymmetric information 
and the use of heuristics in lending in the most parsimonious manner, we differentiate between three different cases:

In the baseline case, the union-wide bank sets both LTV constraints to be constant and equal across regions:

$$
\begin{gathered}
m_{t}^{i, k}=\bar{m}^{i} \forall t, \quad k=\{H, F\}, \\
m_{t}^{E, k}=\bar{m}^{E} \forall t, \quad k=\{H, F\} .
\end{gathered}
$$

Next, in order to capture the effect of asymmetric information on the bank's assessment of creditworthiness and the observed procyclicality of lending standards, we assume that the LTV ratios are time varying and related to the region's previous output gap:

$$
\begin{array}{ll}
m_{t}^{i, k}=\bar{m}^{i}+m_{Y}^{i}\left(\frac{Y_{t-1}^{k}}{\bar{Y}^{k}}-1\right), \quad k=\{H, F\}, \\
m_{t}^{E, k}=\bar{m}^{E}+m_{Y}^{E}\left(\frac{Y_{t-1}^{k}}{\bar{Y}^{k}}-1\right), \quad k=\{H, F\},
\end{array}
$$

where $\bar{Y}^{k}$ represents the $k$-region steady-state output. While this is of course a convenient modeling shortcut, the rationale behind this specification is straightforward: In the real world, banks usually employ a screening mechanism to assess the profitability of the investment projects to be financed, and thus the creditworthiness of the loan applicants. To reflect this, we assume that the bank associates both the value of households' housing collateral as well as firms' investment profitability with the overall business cycle stance of the region's economy. Accordingly, it is natural to assume that a positive output gap-resulting, for instance, from a positive TFP shock-leads to a relaxation of borrowing constraints by the bank as its assessment of credit default risk is reduced. This specification is thus supposed to reflect the procyclicality in lending behavior observable in the Euro area in recent times [Cihák and Brooks (2009)]. Obviously, the determination of $m_{t}^{i, k}$ and $m_{t}^{E, k}$ would be region-specific in the normal case and depend on the core's and the periphery's output gap, respectively. We refer to this case as scenario 1 in the following.

Finally, we consider an additional scenario where the lending standards in both countries regions are determined uniformly solely on the observation of the core region's output gap, i.e.,

$$
\begin{aligned}
& m_{t}^{i, k}=\bar{m}^{i}+m_{Y}^{i}\left(\frac{Y_{t-1}^{F}}{\bar{Y}^{F}}-1\right), \quad k=\{H, F\}, \\
& m_{t}^{E, k}=\bar{m}^{E}+m_{Y}^{E}\left(\frac{Y_{t-1}^{F}}{\bar{Y} F}-1\right), \quad k=\{H, F\} .
\end{aligned}
$$


This alternative specification of $m_{t}^{i, k}$ and $m_{t}^{E, k}$ solely as a function of $\left(Y_{t-1}^{F}-\right.$ $\left.\bar{Y}^{F}\right) / \bar{Y}^{F}$ is meant to represent the heuristic determination of lending standards in cross-border banking within the Euro area discussed for instance by Allen et al. (2011) and CIEPR (2012). In particular, this specification reflects the implicit risk pooling associated with the establishment of monetary unions, and observable in the excessively low sovereign risk premia of EMU countries and resulting interest rate convergence during the 2000s, see, e.g., De Grauwe and Ji (2012) and Proaño et al. (2014). We term this case scenario 2.

\section{SIMULATIONS}

\subsection{Calibration}

For the following simulations, we set our model parameters mainly as in Gerali et al. (2010), who calibrate and partly estimate their model so as to match key aspects of the Euro area real and financial sectors. Additionally, some parameters relating to the open-economy aspect of the model are calibrated as in the two-region model of the Euro area of Engler et al. (2017), which evaluates the effect of a fiscal devaluation using the same definition for the core and periphery regions of EMU. Table 1 reports all constant parameter values used in our simulations. ${ }^{10}$

As in Gerali et al. (2010), the households' discount factor $\beta_{P}$ is set at 0.996, which implies a steady-state deposit and policy rate of about $2 \%$ (annualized). The entrepreneurs' discount factor $\beta_{E}$ is set at 0.975 , as originally in Iacoviello (2005), and the inverse of the Frisch elasticity $\eta$ is set at 1 as in Galí (2008) also. The share of capital in the aggregate production function $\alpha$ is set at 0.20 , and the depreciation rate of physical capital $\delta^{k}$ at 0.025 as in Gerali et al. (2010). Further, we set the adjustment cost for changing prices $\kappa_{p}$ at the value estimated by Gerali et al. (2010) for the Euro area, namely 28.65. The elasticity of substitution across regional goods bundles $\sigma$ is set at 2 as in Engler et al. (2017). Concerning the investment adjustment cost parameter $\kappa^{I}$, we set it at 5 as in Gambacorta and Signoretti (2014) in their analysis of their model's response to technology shocks. ${ }^{11}$

The required LTV ratio for entrepreneurs set by the retail bank branches, $\bar{m}^{E}$, is set at 0.35 in the baseline case, which is similar to the average ratio of long-term loans to the value of shares and other equities for nonfinancial corporations in the Euro area, see also Gerali et al. (2010) as well as Gambacorta and Signoretti (2014). For impatient households, the average LTV ratio $\bar{m}^{I}$ is set at 0.7 , again following Gerali et al. (2010). The sensitivity of both LTV ratios to output gaps in scenarios 1 and 2 is assumed to be 0.5 . The target leverage ratio $v$ and the cost for managing the bank capital position $\delta^{b}$ are set at $9 \%$ and 0.049 , respectively, as in Gerali et al. (2010). Due to the lack of a more direct measure, we set the bank capital adjustment $\operatorname{cost} \theta$ at 11 , the value estimated by Gerali et al. (2010). The bank's elasticity of substitution between loans to home and foreign, $\gamma$, is set 
TABLE 1. Calibration parameters

\begin{tabular}{|c|c|c|}
\hline Parameter & Description & Value \\
\hline$\beta_{p}$ & Patient households' discount factor & 0.9943 \\
\hline$\beta_{i}$ & Impatient households' discount factor & 0.975 \\
\hline$\beta_{e}$ & Entrepreneurs' discount factor & 0.975 \\
\hline$a_{e}$ & Habit formation parameter & 0.8 \\
\hline$j$ & Weight of housing in utility function & 0.2 \\
\hline$\gamma_{p}$ & Share of patient households in the economy & $2 / 5$ \\
\hline$\gamma_{i}$ & Share of impatient households in the economy & $2 / 5$ \\
\hline$\gamma_{e}$ & Share of entrepreneurs in the economy & $1 / 5$ \\
\hline$\xi$ & Share of patient households in the production process & 0.80 \\
\hline$\sigma$ & Elasticity of substitution between home and foreign goods bundles & 2 \\
\hline$\theta^{D}$ & Parameter for households' portfolio adjustment cost & 0.001 \\
\hline $\bar{D}$ & Steady-state level of deposits & 1 \\
\hline$n$ & Home's relative size & 0.34 \\
\hline$\omega^{H}$ & Steady-state import share in home & 0.33 \\
\hline$\omega^{F}$ & Steady-state import share in foreign & 0.17 \\
\hline$\eta$ & Inverse of the Frisch elasticity & 1 \\
\hline$\alpha$ & Capital share in the production function & 0.20 \\
\hline$\xi$ & Wage share of patient households & 0.80 \\
\hline$\phi$ & Inverse of the Frisch elasticity & 1 \\
\hline $\bar{m}^{E}$ & Entrepreneurs' constant LTV ratio & 0.35 \\
\hline$m_{Y}^{I}$ & Output sensitivity of entrepreneurs' LTV ratio & 0.5 \\
\hline$m_{Y}^{E}$ & Output sensitivity of impatient households' LTV ratio & 0.5 \\
\hline $\bar{m}^{I}$ & Impatient households' constant LTV ratio & 0.7 \\
\hline$h$ & Fixed housing supply & 1 \\
\hline$\delta^{k}$ & Depreciation rate of physical capital & 0.025 \\
\hline$\kappa^{I}$ & Investment adjustment cost parameter & 5 \\
\hline$\kappa_{p}$ & Adjustment cost for changing prices & 28.65 \\
\hline$\gamma$ & Bank's elasticity of substitution between lending to both regions & 2 \\
\hline$\theta$ & Bank capital adjustment cost & 11 \\
\hline$v$ & Target capital-to-asset ratio & 0.09 \\
\hline$\delta^{b}$ & Cost for managing the bank's capital position & 0.049 \\
\hline$\phi_{\pi}$ & Inflation gap Taylor rule parameter & 1.5 \\
\hline$\rho$ & Monetary policy inertia & 0.70 \\
\hline$\rho_{m k}$ & Persistence of retailers' cost-push shock & 0.306 \\
\hline$\rho_{a}$ & Persistence of technology shock & 0.936 \\
\hline$\rho_{s}$ & Persistence of discount factor shock & 0.906 \\
\hline$\sigma_{m p}$ & Std. deviation of monetary policy shock & 0.002 \\
\hline$\sigma_{m k}$ & Std. deviation of cost-push shock & 0.634 \\
\hline$\sigma_{a}$ & Std. deviation of technology shock & 0.006 \\
\hline$\sigma_{s}$ & Std. deviation of discount factor shock & 0.018 \\
\hline
\end{tabular}


for simplicity equal to the elasticity of substitution between home and foreign goods bundles, $\sigma$, at 2 . Note that this is in line with the estimates in Poutineau and Vermandel (2015). The degree of monetary policy inertia is set at 0.7 , and $\phi_{\pi}$ is set at 1.5 , as it is standard in the literature.

We set the relative size of the home and foreign economies at 0.34 and 0.66 , respectively, to reflect the asymmetric economic size of the periphery and the core regions of EMU according to our definition [Engler et al. (2017)]. Finally, we adopt the estimated values for the Euro area of the standard deviations of the technology, cost-push and monetary policy shocks (and the autoregressive parameters of the first two) from Gerali et al. (2010), and the estimated values of the standard deviation and the autoregressive parameter of the discount factor shock from Iacoviello and Neri (2010).

\subsection{Asymmetric Technology Shock and Discount Factor Shock to the Core Region}

In order to illustrate the different mechanisms at work in the present theoretical framework, in the following, we discuss the dynamic adjustments of the model's main endogenous variables to an unexpected one-time TFP shock to the core region, as well as to an unexpected one-time discount factor shock also to the core region. In both cases, we assume the baseline scenario with constant LTV ratios for entrepreneurs and impatient households.

As illustrated in Figure 2, the immediate effect of an unexpected asymmetric TFP shock in the core region is an increase in aggregate output and a decrease in price inflation in the core, which leads to a reduction of the policy interest rate by the monetary union's central bank and, by extension, to a reduction in the loan rate. Together with the positive effect of the TFP shock on entrepreneurs' net worth, this boosts aggregate loans in the core and increases investment by entrepreneurs and housing of impatient households. The overall economic expansion leads also to an increase in household private consumption in the core, as well as in housing prices.

Although prices fall in both regions following the TFP shock, they decrease by more in the core which leads to a deterioration of the core's terms of trade (an improvement in the core's competitiveness) and a real exchange rate depreciation. Through the trade channel, over time output in the core is thus additionally boosted by consumers' demand shifting from the periphery to the core, as evident from the response of the trade balance.

Via the financial channel, however, the periphery also benefits somewhat from the TFP shock in the core: As loan rates drop in the periphery as well, after an initial drop in aggregate loans, we observe loans picking up also in the periphery, which leads to an increase in investment by entrepreneurs and housing of impatient households, while aggregate consumption drops for a prolonged period. Hence, aggregate output also rises some periods after the shock, albeit with a smaller expansion than in the core. The fall in loan rates to both regions seems to dominate 

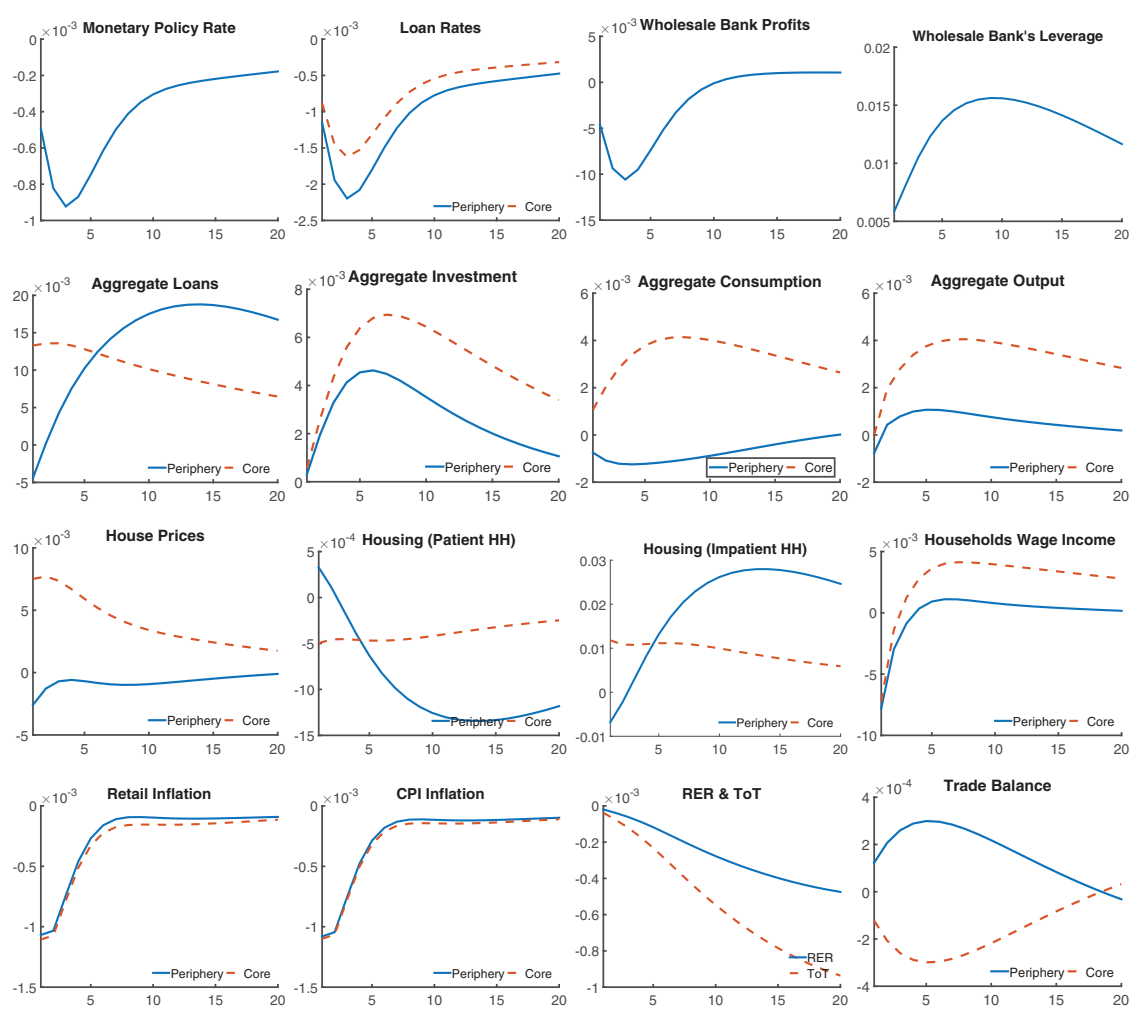

FIGURE 2. Dynamic adjustments after a TFP shock in the core region. All rates are shown as absolute deviations from steady state, expressed in percentage points. All other variables are percentage deviations from their respective steady-state levels.

over the increase in loan supply, as we observe a drop in the bank's profits and a persistent increase in the leverage position.

Next, we evaluate the impact of a stochastic discount factor shock in the core with constant LTV ratios. The discount factor shock causes patient households in the core to become more patient, thus favoring future consumption over current consumption. As shown in Figure 3, this leads to a fall in aggregate consumption as well as aggregate output in the core. The fall in consumption demand from the core also negatively affects demand and retail prices in the periphery. Due to the fall in aggregate demand, retail prices drop in both regions with a deterioration of competitiveness in the core.

The drop in retail prices in both regions following the shock prompts an expansionary monetary policy reaction. As loan rates fall by more than the policy rate, we observe an immediate increase in loans to entrepreneurs and households in the core, while loans in the periphery only subsequently increase. 

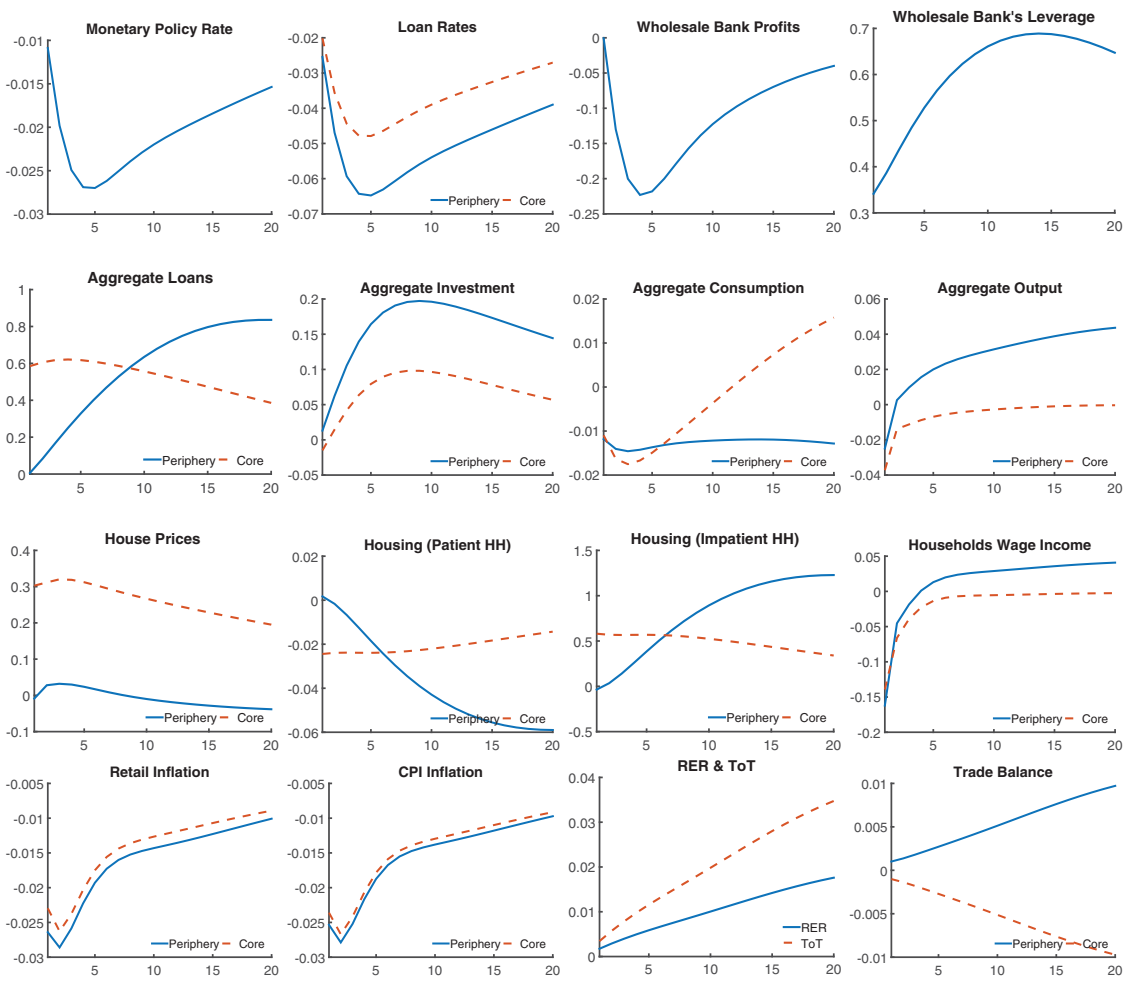

FIGURE 3. Dynamic adjustments after a discount factor shock in the core region. All rates are shown as absolute deviations from steady state, expressed in percentage points. All other variables are percentage deviations from their respective steady-state levels.

Overall, the loss in international competitiveness of the core due to the discount factor shock together with the more sustained boost in loans in the periphery over time leads to a strong boom in aggregate output in the periphery, which is partly driven by the trade channel, as can be observed by the shift in trade balances, and partly by the financial channel.

\subsection{Cross-Border Banking, Rule-of-Thumb Lending Standards and Business Fluctuations}

In this section, we investigate the implications of cross-border banking under asymmetric information and the use of heuristics in the banking sector for macroeconomic activity. Figure 4 illustrates the dynamic adjustment of selected variables of our model to a technology shock in the core under, first, constant LTV ratios (baseline scenario), second, varying region-specific lending standards (scenario 1), and, third, lending standards driven by the core (scenario 2). In all cases, we assume that the output gap of the core is increased by a positive one-standard deviation 

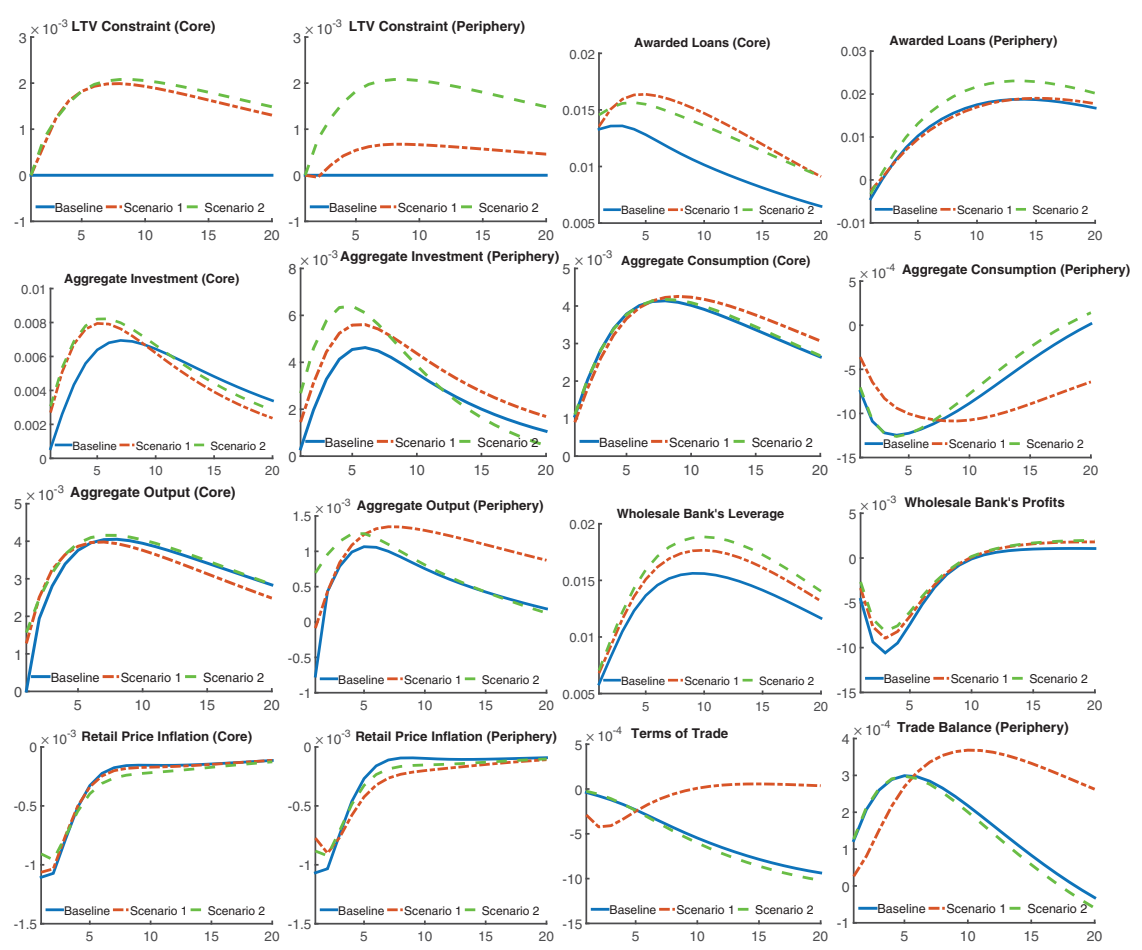

FIGURE 4. Dynamic adjustments to a positive TFP shock in the core under constant (baseline), region-specific (scenario 1), and rule-of-thumb (scenario 2) lending standards. All rates are shown as absolute deviations from steady state, expressed in percentage points. All other variables are percentage deviations from their respective steady-state levels.

shock in that region's TFP, $A_{t}^{F}$, leaving all other variables (and especially TFP in the periphery) unchanged.

As shown in Figure 4, a positive shock to TFP in the core leads to an expansion in aggregate output and investment in that region, the latter being partly financed by an expansion of lending to entrepreneurs and impatient households by the banking sector. Note that this credit expansion takes place also in the baseline case where both LTV ratios stay constant, but is of course larger in magnitude in the two alternative scenarios, where $m^{E, k}$ and $m^{I, k}$ are a direct function of the output gap. In these scenarios, we observe that the LTV ratios increase, which means that households and firms can borrow a larger fraction of their net worth. Due to the higher aggregate income in the core, there is also a higher demand for goods produced there which requires an expansion of the capital stock and thus in the production capacities of the region. This effect takes place in all three scenarios, but is of course largest in scenario 2, where the LTV borrowing constraint (assumed to be a function of the observed output gap in the core) is relaxed not only in the core 
economy (where indeed an increase in TFP took place), but also in the periphery region.

While the reaction of aggregate output in the core differs only marginally between the scenarios (since in any case, the direct impact of the TFP shock on the economy seems to dominate), we clearly observe the effects of cross-border banking with heuristics in the case of the periphery: Awarded loans increase markedly especially in scenario 2 , leading to a faster and more pronounced boost in investment and a smaller reduction of consumption. With banks softening lending standards also in the periphery after the TFP shock in the core, the initial fall in output in the periphery after the shock is overturned into an immediate increase in output. Scenario 2 thus introduces an additional, financial channel via which asymmetric shocks are transmitted in the monetary union.

Interestingly, the dynamics in the periphery economy differ quite substantially between scenarios 1 and 2, with a less pronounced fall in consumption in scenario 1 and a more pronounced medium-term increase in both investment and aggregate output. This is due to a different evolution of prices in the periphery relative to the core when lending standards vary with region-specific output gaps as evident from the response of the terms of trade. Under scenario 1 , the initial fall in the periphery's output is exacerbated by an initial tightening of lending standards which leads to a price path where prices in the periphery remain below those in the core for a prolonged period of time, resulting in an improvement in the periphery's competitiveness position and, hence, its trade balance. This interaction between the trade and the financial channel vanishes once lending standards in the periphery are determined according to the core's output gap which immediately increases after the shock.

Regarding the banking sector, Figure 4 shows that the higher quantity of awarded loans leads to a strong increase in the wholesale bank's leverage in scenarios 2 and 1 compared to the baseline. In all three scenarios, the bank's profits turn positive about 10 periods after the shock, but the initial reduction in profits is lowest in scenario 2. Overall, an extension in cross-border lending caused by rule-of-thumb lending standards driven by the dominant core region leads to an excessive credit expansion (in the sense that it does not occur based on any real changes in the periphery) and a higher leverage in the financial system, and thus to a more fragile macrofinancial situation in comparison to the baseline scenario and the scenario of region-specific lending standards.

Next, we evaluate the effect of rule-of-thumb lending standards on the economy's reaction to a discount factor shock occurring in the core region. As shown in Figure 5, the discount factor shock leads patient households to prefer future over current consumption, which causes consumption, output, and to a lesser extent also investment, in the core to fall. Via both the trade channel and the financial channel, consumption and output initially fall also in the periphery. The shock thus leads to an initial drop in aggregate output in both regions, which in scenarios 1 and 2 causes banks to enforce stricter lending conditions as firms and households are only allowed to borrow against a smaller fraction of their net worth, equivalent 

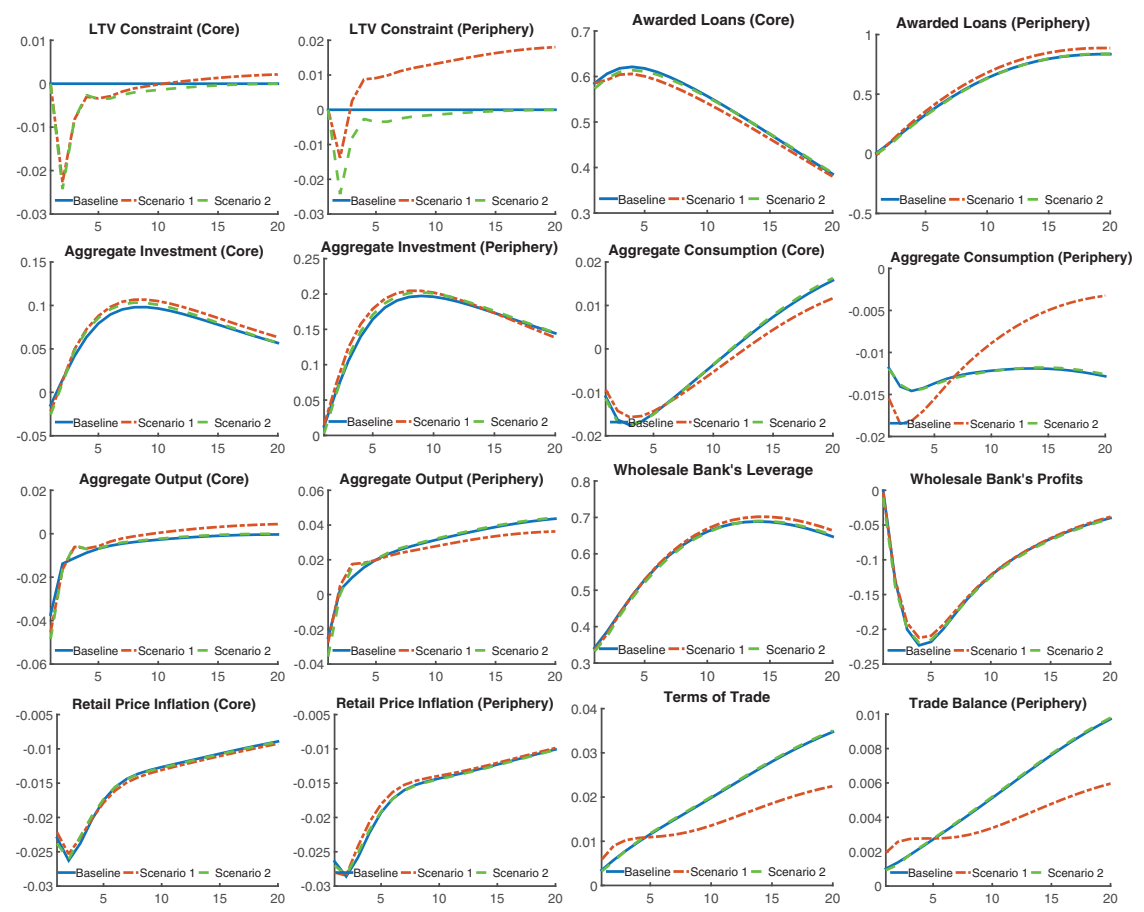

FIGURE 5. Dynamic adjustments to a positive discount factor shock in the core under constant (baseline), region-specific (scenario 1), and rule-of-thumb (scenario 2) lending standards. All rates are shown as absolute deviations from steady state, expressed in percentage points. All other variables are percentage deviations from their respective steady-state levels.

to a drop in the LTV constraint. This effect becomes stronger in the periphery in scenario 2 where the larger fall in output in the core is translated also in a larger drop of the LTV ratio in the periphery.

Since loan rates drop together with the expansive monetary policy reaction to the discount factor shock in both regions, as shown in Figure 3, awarded loans increase in both regions in spite of stricter lending conditions. Investment picks up more quickly in both regions as lending conditions improve again in scenarios 1 and 2, leading to a faster recovery of output after the shock. Overall, we note that the different lending scenarios affect the regions' aggregate response to the discount factor shock by less than in the case of the TFP shock. This is because the discount factor shock influences patient households who are not directly affected by changes in lending standards. By contrast, a positive technology shock directly improves entrepreneurs' lending position. However, there is a remarkable effect on the terms of trade and the trade balances in scenario 1, which in turn affects the consumption path of each region: Because retail prices fall initially more in the periphery than in the core region, the terms of trade shift in favor of the 
periphery, leading to an improvement of its trade balance in the short-run and a faster recovery of periphery consumption.

Finally, in order to assess the empirical validity of our model across the alternative specifications of the LTV borrowing constraints, in Table 2, we compute the theoretical second moments of the Hodrick-Prescott filtered series (using $\lambda=1,600$ given the underlying quarterly frequency of the model) as well as auto- and cross-correlations of the main variables of the model and compare these to moments of actual data. Data are obtained from the OECD for the macrovariables and from the ECB for the financial variables. We define the core of the EMU to consist of Germany, France, the Netherlands, Finland, Belgium, and Austria, and the periphery to include Spain, Greece, Portugal, Ireland, and Italy. We take logarithms of the data (except for interest rates and prices) and evaluate the moments of HP-filtered series in line with the data obtained from the simulations. All data are quarterly and generally available from $1999 q 1$ to $2016 q 1$, with data on loan rates available only for 2003q1-2016q1. We choose variables in line with our model variables, where loan rates are proxied with interest rates on housing loans. ${ }^{12}$

Table 2 reports a variety of results worth highlighting. First, while the absolute values of the standard deviations of real aggregates in both regions are three to four times larger in the model scenarios than their empirical counterparts, when expressed in terms of the respective aggregate outputs, our three model variants match these ratios with their empirical analogs remarkably closely (with the sole exception of periphery consumption). The absolute standard deviations of loan rates and inflation are, unfortunately, not matched as closely by our model. Moreover, the empirical data show that the aggregate consumption, investment, loan rates, and inflation were more volatile in the periphery relative to the core over our sample period. This stylized fact is also matched by our model simulation across all scenarios.

As for the persistence of the variables summarized in Table 2, their first-order autocorrelation appears quite realistic when compared to the data moments. Further, while the dynamic (first lag) cross-correlations between the periphery and the core regions (third and fourth columns) deliver a somewhat mixed picture, the contemporaneous correlations (fifth column) between the periphery and the core variables are again remarkably similar to their empirical analogs in most cases.

In summary, both the data and our model imply that the core and the periphery regions of the EMU closely comove with respect to the dynamics of both real and nominal variables, with the contemporaneous correlations $\operatorname{Corr}\left(x_{t}^{F}, x_{t}^{H}\right)$ being usually higher than $\operatorname{Corr}\left(x_{t}^{H}, x_{t-1}^{F}\right)$ and $\operatorname{Corr}\left(x_{t}^{F}, x_{t-1}^{H}\right)$. Overall, it seems that our model is able to capture the dynamics within and between EMU regions quite well.

Summing up, the numerical results discussed in this section suggest that crossborder lending activities, especially with time-varying and procyclical lending standards, can contribute to the magnification of macroeconomic fluctuations. ${ }^{13}$ This may eventually lead to sudden busts as was the case in Spain and Ireland. 
TABLE 2. Empirical and theoretical moments of the Hodrick-Prescott filtered series $(\lambda=1,600)$ of the key model variables (standard deviations of aggregate consumption and investment in the core and periphery regions are expressed relative to the respective output standard deviations)

\begin{tabular}{|c|c|c|c|c|c|}
\hline Variable & $\begin{array}{c}\text { Std. } \\
\text { deviation }\end{array}$ & $\begin{array}{c}\text { Corr } \\
\left(x_{t}, x_{t-1}\right)\end{array}$ & $\begin{array}{c}\text { Corr } \\
\left(x_{t}^{H}, x_{t-1}^{F}\right)\end{array}$ & $\begin{array}{c}\text { Corr } \\
\left(x_{t}^{F}, x_{t-1}^{H}\right)\end{array}$ & $\begin{array}{c}\text { Corr } \\
\left(x_{t}^{F}, x_{t}^{H}\right)\end{array}$ \\
\hline Periphery output $Y^{H}-$ Actual data & 0.014 & 0.910 & 0.488 & - & 0.601 \\
\hline - Baseline & 0.064 & 0.592 & 0.038 & - & 0.205 \\
\hline - Scenario 1 & 0.072 & 0.507 & 0.048 & - & 0.247 \\
\hline - Scenario 2 & 0.072 & 0.522 & 0.150 & - & 0.434 \\
\hline Core output $Y^{F}-$ Actual data & 0.015 & 0.893 & - & 0.619 & - \\
\hline - Baseline & 0.055 & 0.403 & - & -0.143 & - \\
\hline - Scenario 1 & 0.067 & 0.340 & - & -0.156 & - \\
\hline - Scenario 2 & 0.071 & 0.292 & - & -0.126 & - \\
\hline Periphery consumption $C^{H}-$ Actual data & 1.071 & 0.880 & 0.072 & - & 0.432 \\
\hline - Baseline & 0.138 & 0.815 & 0.455 & - & 0.513 \\
\hline - Scenario 1 & 0.586 & 0.799 & 0.539 & - & 0.532 \\
\hline - Scenario 2 & 0.494 & 0.814 & 0.456 & - & 0.521 \\
\hline Core consumption $C^{F}-$ Actual data & 0.333 & 0.840 & - & 0.231 & - \\
\hline - Baseline & 0.141 & 0.889 & - & 0.491 & _- \\
\hline - Scenario 1 & 0.463 & 0.876 & - & 0.490 & _- \\
\hline - Scenario 2 & 0.480 & 0.889 & - & 0.501 & - \\
\hline Periphery investment $I^{H}-$ Actual data & 3.286 & 0.832 & 0.485 & - & 0.605 \\
\hline - Baseline & 3.763 & 0.937 & 0.757 & - & 0.861 \\
\hline - Scenario 1 & 3.650 & 0.928 & 0.748 & - & 0.873 \\
\hline - Scenario 2 & 3.563 & 0.929 & 0.739 & - & 0.877 \\
\hline Core investment $I^{F}-$ Actual data & 2.214 & 0.904 & - & 0.652 & - \\
\hline - Baseline & 2.715 & 0.898 & - & 0.858 & - \\
\hline - Scenario 1 & 2.475 & 0.872 & - & 0.748 & - \\
\hline - Scenario 2 & 2.384 & 0.857 & - & 0.739 & - \\
\hline Periphery loan rate $r^{b H}-$ Actual data & 0.413 & 0.887 & 0.510 & - & 0.984 \\
\hline - Baseline & 0.090 & 0.896 & 0.890 & - & 0.999 \\
\hline - Scenario 1 & 0.088 & 0.897 & 0.889 & - & 0.998 \\
\hline - Scenario 2 & 0.088 & 0.896 & 0.889 & - & 0.999 \\
\hline Core loan rate $r^{b F}-$ Actual data & 0.292 & 0.758 & - & 0.789 & - \\
\hline - Baseline & 0.066 & 0.895 & - & 0.900 & - \\
\hline - Scenario 1 & 0.064 & 0.896 & - & 0.901 & - \\
\hline - Scenario 2 & 0.065 & 0.895 & - & 0.900 & - \\
\hline Periphery CPI inflation $\pi^{H}-$ Actual data & 0.836 & 0.829 & 0.672 & - & 0.887 \\
\hline - Baseline & 0.042 & 0.681 & 0.680 & - & 0.956 \\
\hline - Scenario 1 & 0.041 & 0.655 & 0.661 & - & 0.917 \\
\hline - Scenario 2 & 0.041 & 0.668 & 0.667 & - & 0.956 \\
\hline Core CPI inflation $\pi^{F}-$ Actual data & 0.685 & 0.824 & - & 0.813 & - \\
\hline - Baseline & 0.040 & 0.685 & - & 0.674 & - \\
\hline - Scenario 1 & 0.039 & 0.679 & - & 0.634 & - \\
\hline- Scenario 2 & 0.039 & 0.679 & - & 0.668 & - \\
\hline
\end{tabular}


Further, the results highlight the need of a strict regulation of the financial system and the lending standards, in particular, given the perfect mobility of capital within monetary unions such as the Euro area. We discuss the role of different macroprudential policy scenarios in the next section.

\subsection{The Role of Macroprudential Policies}

In the following, we analyze the performance of several macroprudential policy measures in terms of their potential to stabilize aggregate output and the wholesale bank's leverage ratio, which we take as a proxy for financial stability in the banking sector. We simulate the impact of macroprudential policies both in scenario 1 with region-specific time-varying LTV ratios and in scenario 2 where the bank sets LTV ratios in both regions in response to output gap fluctuations in the core.

\section{Policy 1: Countercyclical LTV ratio}

The first macroprudential policy we consider, which is also widely discussed in the literature, aims to enforce macroeconomic stability by making the LTV behave in a countercyclical, and not a procyclical manner [see, e.g., Brzoza-Brzezina et al. $(2015)]^{14}$ :

$$
m_{t}^{E, k}=\bar{m}^{E}+\left(m_{Y}^{E}-\phi_{Y}^{m}\right)\left(\frac{Y_{t-1}^{F}}{\bar{Y} F}-1\right), \quad k=\{H, F\},
$$

where $\phi_{Y}^{m}$ is the macroprudential parameter in control of the policy authorities which decreases the procyclicality of the LTV ratio, or even reverses it if a value large enough is set.

\section{Policy 2: Leverage-dependent LTV ratio}

Under this second macroprudential policy, the LTV ratio additionally depends on the bank's leverage ratio:

$$
m_{t}^{E, k}=\bar{m}^{E}+m_{Y}^{E}\left(\frac{Y_{t-1}^{F}}{\bar{Y}^{F}}-1\right)+\phi_{K B}^{E}\left(\frac{K_{t}^{b}}{B_{t}}-v\right), \quad k=\{H, F\} .
$$

Accordingly, when the capital-to-loan ratio of the bank is higher than the target leverage level $v$, they can relax their credit standards by increasing the LTV ratio. By the same token, when the bank's financial situation implies that its capital-to-loan ratio is lower than $v$, the LTV ratio is reduced. This policy is thus meant to safeguard the stability of the banking sector in a conservative manner, where the parameter $\phi_{K B}^{E}$ measures the strength of this macroprudential instrument.

\section{Policy 3: Stricter capital adequacy requirement}

Another way of tackling the problem of a too lax credit awarding by banks both in the periphery and in the core of the monetary union is to increase the 
capital-to-loan target ratio $v$. Under the third macroprudential policy experiment, we thus increase the value of $v$ in the simulations.

\section{Policy 4: Varying costs of deviating from the capital adequacy requirement}

The fourth and last macroprudential policy experiment we consider here consists of increasing the costs for the bank of deviating from the legally set target leverage ratio $v$. In terms of our theoretical model, this translates into an increase in the parameter $\theta$, see equation (46). Economically, a higher $\theta$ requires a closer monitoring and fulfillment of the capital-to-loan requirements by the wholesale branch, and thus - in the aggregate and over time - is likely to lead to less excessive lending and a more regular fulfillment of the capital adequacy requirements. ${ }^{15}$

Figure 6 comprises the performance of these four macroprudential policies concerning the stabilization of aggregate output in the periphery and in the core region of the monetary union, as well as the stabilization of the leverage of the wholesale bank branch in the two scenarios. Note that the $x$-axis measures the increase in each policy parameter, respectively.

As can be clearly observed, there is significant heterogeneity in the performance of the alternative macroprudential policies considered here: The results suggest that the implementation of the macroprudential policy measure 1 [forcing the LTV ratios, and hence lending standards, to be less procyclical or even countercyclical, as also assumed in Brzoza-Brzezina et al. (2015)] delivers the best performance in terms of aggregate output stabilization for both the core and the periphery region, at the expense, however, of the stabilization of the wholesale bank's leverage ratio. Further, it is interesting to note that in scenario 2 the gains of higher values of $\phi_{Y}^{m}$ in terms of the stabilization of the periphery output decrease as $\phi_{Y}^{m}$ increases above a certain threshold value. This is because we assume that the banks' lending standards in both regions react to changes in the output gap in the core, thus forcing them to be overly strict for the periphery economy if $\phi_{Y}^{m}$ becomes very large. This effect is, however, not present in scenario 1, where lending standards depend only on the macroeconomic conditions of each region, respectively.

The second best policy concerning output stabilization is interestingly at the same time the best strategy concerning the stabilization of the wholesale bank's leverage ratio, namely policy 3: The enforcement of stricter capital adequacy requirements (the union-wide bank's target leverage ratio $v$ ). ${ }^{16}$ It thus seems that forcing the bank to be more conservative in terms of aggregate leverage also reduces some part of the excessive credit dynamics over the business cycle, especially in the periphery. Further, it is also noteworthy that policy 2 [described in equation (56)], where LTV ratios are made to depend directly on the bank's leverage position, has a poor performance in terms of aggregate output stabilization in both the cases and for both the regions, with a negligible effect on the bank's leverage stabilization even though the bank's leverage is the target variable for this policy. Finally, increasing the cost of deviating from the leverage target in macroprudential policy 4 does not seem to significantly affect either the volatility of aggregate output or that of the bank's leverage ratio. 
Aggregate Output (Periphery)

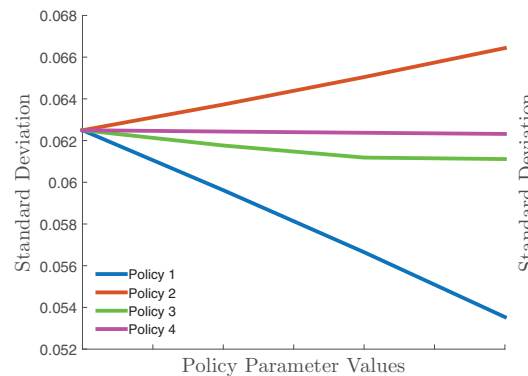

Policy Parameter Values

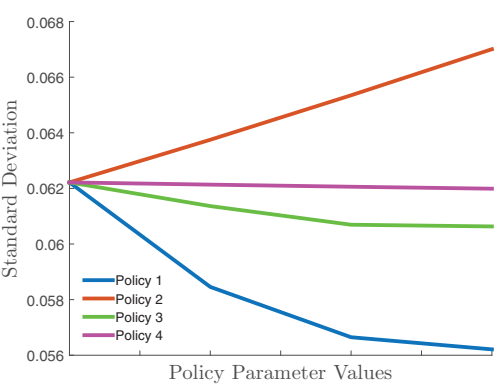

Aggregate Output (Core) Wholesale Bank's Leverage

Scenario 1

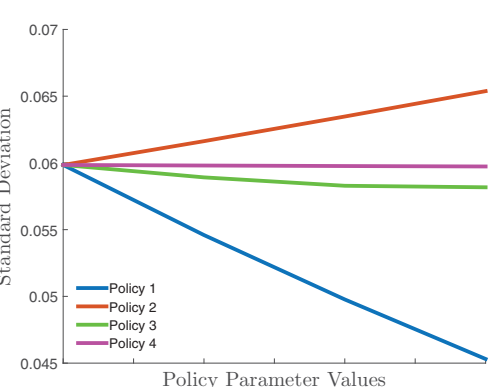

Scenario 2

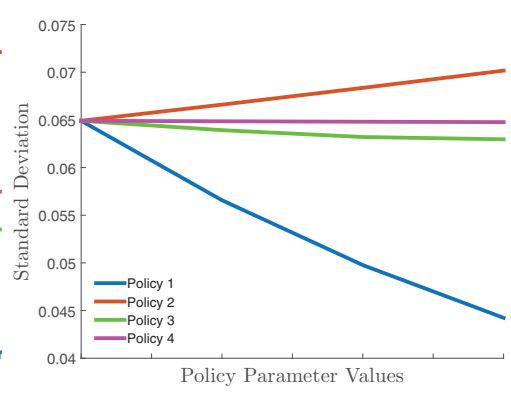

FIGURE 6. Standard deviations of aggregate output in the two regions and the leverage of the wholesale bank branch for different macroprudential policy parameters $\left(\phi_{Y}^{m}=\{0,0.25,0.5,1,1.5\}, \phi_{K B}^{E}=\{0,0.05,0.1,0.15,0.2\}, v=\{0.09,0.099,0.108,0.117,0.126\}\right.$, and $\theta=\{11,11.25,11.5,11.75,12\})$ for scenario 1 (first row) and scenario 2 (second row). 


\section{CONCLUDING REMARKS}

What are the macroeconomic consequences of cross-border banking and a heuristic and procyclical determination of lending standards? How can the destabilizing effects of the financial channel be mitigated by macroprudential policies? In this paper, we try to shed some light onto these questions by setting up a two-region DSGE model of a monetary union featuring a union-wide financially constrained banking sector along the lines of Gerali et al. (2010) and Gambacorta and Signoretti (2014), which allows us to differentiate the effects of cross-border lending from the standard trade links of two interacting economies in a monetary union.

Against the background of the recent emergence of macroeconomic imbalances within the EMU, we investigate the macroeconomic consequences of asymmetric and procyclical lending standards applied in a cross-border manner. Specifically, we compare a scenario where the LTV ratio that banks demand of entrepreneurs and households depends on the regional output gaps to a scenario where desired LTV ratios are driven by the output gap from the core region, thereby relaxing borrowing constraints for all borrowers in the monetary union after a positive output gap in that region. The latter scenario is motivated by the observation of converging risk premia after the start of EMU as financial markets applied the low risk standards of the core region throughout the whole monetary union.

Our model is able to capture important characteristics of EMU data, such as the higher standard deviations of most macroeconomic variables in the periphery compared to the core, and the persistence and cross-regional correlations of the main macrovariables. Our simulation results suggest that such type of crossborder lending practices amplifies the effects of region-specific technology and discount factor shocks in both regions of the monetary union, leading to business fluctuations in the periphery after shocks in the core that are generated by the change in lending standards, and not by corresponding changes in macroeconomic fundamentals. Furthermore, such developments lead to a significant increase in the volatility of all main macrovariables in both regions of the monetary union. We thus show that under certain conditions the financial channel may exacerbate macroeconomic imbalances originating via the trade channel within the monetary union.

Given the significant effects that such a larger aggregate volatility implies in terms of welfare costs, we conduct several policy experiments testing for the effect of different macroprudential policies in reducing output volatility in both regions of the monetary union as well as the volatility of the leverage position in the banking sector. We can show that policies aiming at reducing the procyclicality of lending standards captured by the LTV ratios demanded by banks are particularly helpful in reducing output volatility across the monetary union. In addition, increasing the leverage target of the banking sector apart from stabilizing bank leverage also has a benefitial impact on output stabilization in both regions. By contrast, policies that increase the costs of deviating from the leverage target or that make the allowed 


\section{LTV ratios dependent on the leverage position of the banking sector either have only small or even detrimental effects on output volatility.}

\section{NOTES}

1. We disregard very small countries such as Luxembourg, Malta, and Cyprus, as well as the Baltic countries that only very recently joined EMU.

2. The diffusion index is defined as the difference between the weighted sum of the percentages of banks stating "tightened considerably" and "tightened somewhat" and the weighted sum of the percentages of banks stating "eased considerably" and "eased somewhat." Answers with "considerably" receive a weight of 1 and answers with "somewhat" a weight of 0.5 . The index has a range from -100 to +100 . See https://www.ecb.europa.eu/stats/pdf/ecbblsglossary.en.pdf for more details.

3. Unfortunately, the bank lending survey data for Finland are not available, so that the core here consists only of Germany, France, the Netherlands, Belgium, and Austria. The survey is available from 2003q1 to 2016q2.

4. Since labor mobility in the EMU is arguably still considerably lower compared to other regions such as the United States, we incorporate this simplifying assumption in the model. An extension accounting also for labor mobility is left for future research.

5. Note that the assumption of a symmetric steady state with equal per-capita output in the two regions implies that the amount of home bias in both regions is related to the relative region size: $\omega^{F}=\frac{n}{1-n} \omega^{H}$.

6. Note that given the assumed home bias in consumption, the households' aggregate consumption bundles in the periphery $H$ and the core $F$ and the corresponding price indices are not necessarily symmetric. For detailed derivations, we refer to the previously referred papers, and to the online appendix of this paper.

7. Note that we assume the loan rate to be equal for impatient households and firms and only to differ across regions. Nevertheless, banks may distinguish between loans granted to firms or households via the amount of borrowing granted given their specific LTV ratios in the borrowing constraint.

8. This seems to be a reasonable assumption for a model of the EMU, since bank credit is the predominant source of external finance for European firms, see, for instance, Allen et al. (2011).

9. This assumption implies that throughout the monetary union, the market structure among retail banks is similar. Since we assume that the representative bank acts internationally in both regions of the monetary union, this assumption seems reasonable. The equilibrium spread between the retail loan rates $r^{b H}$ and $r^{b F}$ and the policy rate $r^{d}$ is then a function of the markup $\bar{\mu}^{b}$, the relative region size $n$, the substitution elasticity $\gamma$, as well as the equilibrium share of lending to each region.

10. We also considered estimating the current framework with disaggregated Euro area data, but decided against it because a proper estimation of the cross-border banking effects at work here would be a task beyond the scope of this paper due to their overlap with the global financial liberalization since the 2000s. We leave this for further research.

11. Gambacorta and Signoretti (2014) set $\kappa^{I}$ at 0.5 when analyzing cost-push shocks, but argue that when both technology and cost-push shocks hit their model at the same time, their overall results are not affected by the choice of a particular value of $\kappa^{I}$, see Gambacorta and Signoretti (2014, p. 155-56).

12. The detailed data sources are given in Table A.1 in the appendix.

13. This result is in line with the empirical analysis in Mittnik and Semmler (2018) who report that a highly leveraged banking system can result in instabilities and downward macroeconomic spirals.

14. In the following, we focus on variations of the entrepreneurs' LTV ratio, leaving the LTV ratio of the impatient households constant. The reason for this is that we want to study the effect of alternative macroprudential policies on aggregate investment in isolation.

15. Note that both policy 3 and policy 4 imply also a change in the steady state of the model.

16. Note that this policy implies a change in the steady-state leverage ratio which may have nontrivial consequences in terms of welfare. These results should thus be taken with a grain of salt. 


\section{REFERENCES}

Allen, F., T. Beck, E. Carletti, P. R. Lane, D. Schoenmaker, and W. Wagner (2011) Cross-Border Banking in Europe: Implications for Financial Stability and Macroeconomic Policies. Technical report, Centre for Economic Policy Research (CEPR).

Beetsma, R. and H. Jensen (2005) Monetary and fiscal policy interactions in a micro-founded model of a monetary union. Journal of International Economics 67(2), 320-352.

Benigno, P. (2004) Optimal monetary policy in a currency area. Journal of International Economics 63(2), 293-320.

Bernanke, B., M. Gertler, and S. Gilchrist (1999) The financial accelerator in a quantitative business cycle. In J. B. Taylor and M. Woodford (eds.), Handbook of Macroeconomics, vol. 1, Part C, pp. 1341-1393. Amsterdam, Netherlands: Elsevier North Holland.

BIS (2010) International Banking and Financial Market Developments. Quarterly Review, March 2010, Bank for International Settlements.

BIS (2011) 81st Annual Report. Technical report, Bank for International Settlements.

Borio, C. and P. Disyatat (2011) Global Imbalances and the Financial Crisis: Link or No Link?. BIS working paper 346.

Brzoza-Brzezina, M., M. Kolasa, and K. Makarski (2015) Macroprudential policy and imbalances in the Euro area. Journal of International Money and Finance 51, 137-154.

CIEPR (2012) Banks and Cross-Border Capital Flows: Policy Challenges and Regulatory Responses. Technical report, Comittee on International Economic Policy and Reform.

Cihák, M. and P. K. Brooks (2009) From Subprime Loans to Subprime Growth? Evidence for the Euro Area. IMF working paper WP/09/69.

Cúrdia, V. and M. Woodford (2010) Credit frictions and optimal monetary policy. Journal of Money, Credit \& Banking 42(s1), 3-35.

De Grauwe, P. and Y. Ji (2012) Mispricing of sovereign risk and macroeconomic stability in the eurozone. Journal of Common Market Studies 50(6), 866-880.

Dräger, L. and C. R. Proaño (2015) Cross-Border Banking and Business Cycles in Asymmetric Currency Unions. Discussion paper 21/2015, Deutsche Bundesbank, Frankfurt a.M.

Duarte, M. and A. L. Wolman (2008) Fiscal policy and regional inflation in a currency union. Journal of International Economics 74(2), 384-401.

Engler, P., G. Ganelli, J. Tervala, and S. Voigts (2017) Fiscal devaluation in a monetary union. IMF Economic Review 65(2), 241-272.

Ferrero, A. (2009) Fiscal and monetary rules for a currency union. Journal of International Economics $77(1), 1-10$.

Galí, J. and T. Monacelli (2008) Optimal monetary and fiscal policy in a currency union. Journal of International Economics 76(1), 116-132.

Galí, Jordi (2008) Monetary Policy, Inflation and the Business Cycle. Princeton, NJ: Princeton University Press.

Gambacorta, L. and F. M. Signoretti (2014) Should monetary policy lean against the wind? An analysis based on a DSGE model with banking. Journal of Economic Dynamics \& Control 43(C), 146174.

Gerali, A., S. Neri, L. Sessa, and F. M. Signoretti (2010) Credit and banking in a DSGE model of the Euro area. Journal of Money, Credit and Banking 42(s1), 107-141.

Gnimassoun, B. and V. Mignon (2016) How do macroeconomic imbalances Interact? Evidence from a panel VAR analysis. Macroeconomic Dynamics 20(7), 1717-1741.

Gruss, B. and S. Sgherri (2009) The Volatility Costs of Procyclical Lending Standards: An Assessment Using a DSGE Model. IMF working paper 09/35.

Hristov, N., O. Hülsewig, and T. Wollmershäuser (2014) The interest rate pass-through in the Euro Area during the global financial crisis. Journal of Banking \& Finance 48, 104-119.

Iacoviello, M. (2005) House prices, borrowing constraints and monetary policy in the business cycle. American Economic Review 95(3), 739-764. 
Iacoviello, M. and S. Neri (2010) Housing market spillovers: Evidence from an estimated DSGE model. American Economic Journal: Macroeconomics 2, 125-164.

in 't Veld, J., R. Kollmann, B. Pataracchia, M. Ratto, and W. Roeger (2014) International capital flows and the boom-bust cycle in Spain. Journal of International Money and Finance 48, 314-335.

Kalemli-Ozcan, S., E. Papaioannou, and F. Perri (2013) Global banks and crisis transmission. Journal of International Economics 89(2), 495-510.

Kamber, G. and C. Thoenissen (2013) Financial exposure and the international transmission of financial shocks. Journal of Money Credit, and Banking 45(2), 127-158.

Kleimeier, S., H. Sander, and S. Heuchemer (2013) Financial crises and cross-border banking: New evidence. Journal of International Money and Finance 32, 884-915.

Kollmann, R., Z. Enders, and G. Müller (2011) Global banking and international business cycles. European Economic Review 55(3), 407-426.

Lambertini, L., C. Mendicino, and M. T. Punzi (2013) Leaning against boom-bust cycles in credit and housing prices. Journal of Economic Dynamics \& Control 37, 1500-1522.

Maddaloni, A. and J.-L. Peydrò (2013) Monetary Policy, Macroprudential Policy and Banking Stability-Evidence from the Euro Area. ECB working paper 1560.

Mittnik, S. and W. Semmler (2018) Overleveraging, financial fragility, and the banking-macro link: Theory and empirical evidence. Macroeconomic Dynamics 22(1), 4-32.

Obstfeld, M. and K. Rogoff (2001) The six major puzzles in international macroeconomics: Is there a common cause? In B. S. Bernanke and K. Rogoff (eds.), NBER Macroeconomics Annual 2000, vol. 15, pp. 339-412. Cambridge, MA: MIT Press.

Poutineau, J.-C. and G. Vermandel (2015) Cross-border banking flows spillovers in the Eurozone: Evidence from an estimated DSGE model. Journal of Economic Dynamics \& Control 51, 378-403.

Proaño, C. R., C. Schoder, and W. Semmler (2014) Financial stress, sovereign debt and economic activity in industrialized countries: Evidence from dynamic threshold regressions. Journal of International Money and Finance 45, 17-37.

Quint, D. and P. Rabanal (2014) Monetary and macroprudential policy in an estimated DSGE model of the Euro Area. International Journal of Central Banking 10(2), 169-236.

Rotemberg, Julio J. (1982) Sticky prices in the United States. Journal of Political Economy 90(6), 1187 1211.

Schmitt-Grohé, Stephanie and Martín Uribe (2003) Closing small open economy models. Journal of International Economics 61(1), 163-185.

Ueda, K. (2012) Banking globalization and international business cycles: Cross-border chained credit contracts and financial accelerators. Journal of International Economics 86(1), 1-16.

\section{APPENDIX}

TABLE A.1. Data sources

\begin{tabular}{llcc}
\hline Variable & \multicolumn{1}{c}{ Name } & Source & \multicolumn{1}{c}{ Sample } \\
\hline Output & Real gross domestic output & OECD & 1999q1-2016q1 \\
Consumption & Real final consumption expenditures & OECD & $1999 q 1-2016 q 1$ \\
Investment & Real gross fixed capital formation & OECD & $1999 q 1-2016 q 1$ \\
Loan rate & Interest on housing loans & ECB & 2003q1-2016q1 \\
CPI inflation & Harmonized consumer price index inflation & ECB & $1999 q 1-2016 q 1$ \\
\hline
\end{tabular}

